\title{
Bangladesh: Financial System Stability Assessment
}

This Financial System Stability Assessment on Bangladesh was prepared by a staff team of the International Monetary Fund and the World Bank as background documentation for the periodic consultation with the member country. It is based on the information available at the time it was completed on July 30, 2009. The assessment was further discussed during the Article IV consultation mission of October 2009 and took into account recent developments. The views expressed in this document are those of the staff team and do not necessarily reflect the views of the government of Bangladesh or the Executive Board of the IMF.

The policy of publication of staff reports and other documents by the IMF allows for the deletion of market-sensitive information.

Copies of this report are available to the public from

International Monetary Fund • Publication Services 700 19th Street, N.W. • Washington, D.C. 20431

Telephone: (202) 623-7430 • Telefax: (202) 623-7201

E-mail: publications@imf.org • Internet: http://www.imf.org

\section{International Monetary Fund Washington, D.C.}




\title{
INTERNATIONAL MONETARY FUND
}

\section{BANGLADESH}

\section{Financial System Stability Assessment}

\author{
Prepared by the Monetary and Capital Markets and Asia and Pacific Departments
}

\author{
Approved by José Viñals and Anoop Singh
}

December 23, 2009

\begin{abstract}
This Financial System Stability Assessment is based on a Financial Sector Assessment Program (FSAP) mission undertaken from July 19 to 30, 2009. The assessment was further discussed during the Article IV consultation mission of October 2009 and took into account recent developments.
\end{abstract}

The team comprised Rodolfo Maino (co-Lead, IMF), Robert Kahn (co-Lead, World Bank), Juan Buchenau, Miquel Dijkman, Olivier Hassler, Varsha Marathe, and Luchia Christova (all World Bank); Romain Veyrune, Moses Kitonga, and Elod Takats (all IMF), and James Hanson and Diane Mendoza (expert consultants). The mission was supported by Jonathan Dunn, the IMF Resident Representative in Dhaka. The main findings of the assessment were:

- The soundness of the financial sector has been strengthened since the 2003 FSAP. Nonperforming loans in the banking system have decreased steadily since 2003, and the stated capital position of banks has strengthened. Meanwhile, the total assets of the banking system have doubled during this period and credit to the private sector has risen threefold. The rapid growth in non-traditional banking activities in recent years is generating new risks, underlining the importance of strengthening the regulatory framework.

- Nevertheless, significant long-standing risks and vulnerabilities remain. Loan classification, provisioning, and even capital remain uneven in the banking sector, creating potential vulnerabilities. Non-prudential government intervention — such as interest rate ceilings, moral suasion, directed credit and explicit requirements to ease debt service for some sectors of the economy-increases risks, reduces transparency, and creates inefficiencies. Moreover, inadequate information, attributable to nontransparent accounting and reporting, affects market discipline.

- Stress tests suggest that credit risk continues to have a larger impact relative to other single-factor shocks. Exchange-rate risk does not present a major threat because the net open positions of many banks are negligible. Since the country relies heavily on remittances and exports, a protracted global economic slowdown could affect banks' asset quality. Although financial soundness indicators are generally favorable, the asset quality of commercial loans portfolios remains weak, with a large share of loans classified in the substandard, doubtful, and loss categories. Despite the major improvements resulting from Bangladesh Bank's restructuring program including the corporatization of state banks, they remain financially weak.

The main author of this report is Rodolfo Maino.

FSAP assessments are designed to assess the stability of the financial system as a whole and not that of individual institutions. They have been developed to help countries identify and remedy weaknesses in their financial sector structure, thereby enhancing their resilience to macroeconomic shocks and cross-border contagion. FSAP assessments do not cover risks that are specific to individual institutions such as asset quality, operational or legal risks, or fraud. 
Glossary 3

Overall Assessment, Stability and Development Issues ................................................................... 4

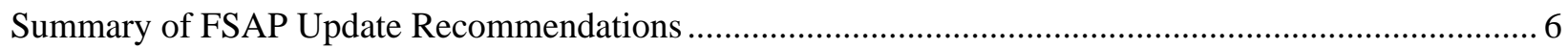

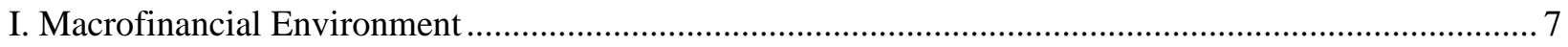

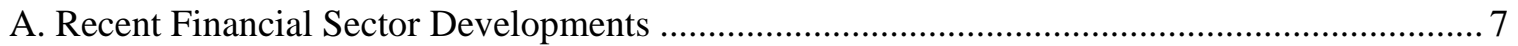

B. Monetary Policy Framework, Liquidity Management, and FX Operations .............................. 9

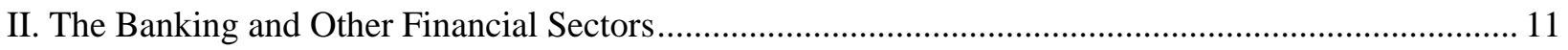

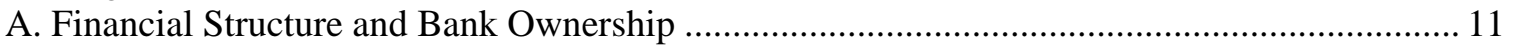

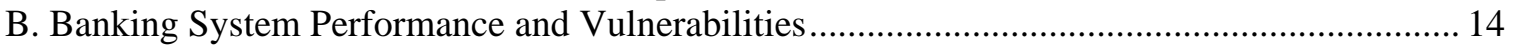

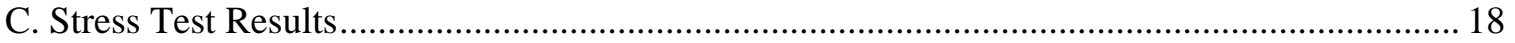

III. Risk Mitigation: Financial Safety Nets and Crisis Management Capabilities ................................... 21

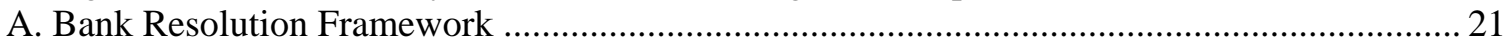

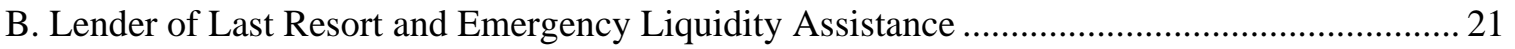

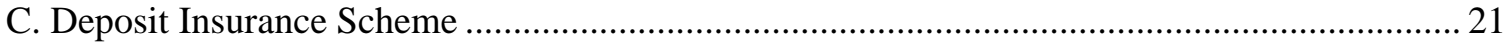

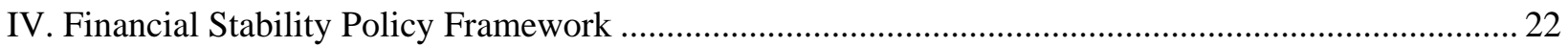

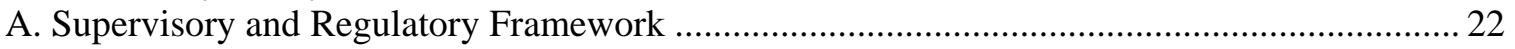

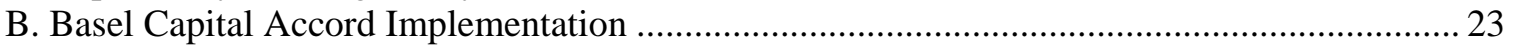

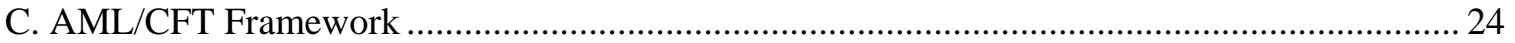

Figures

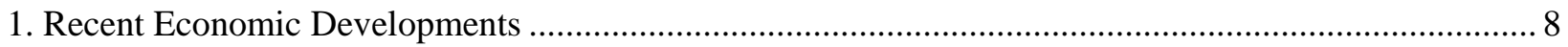

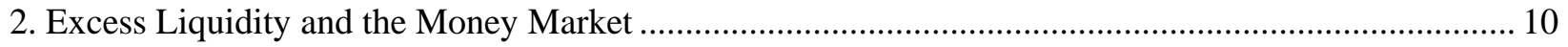

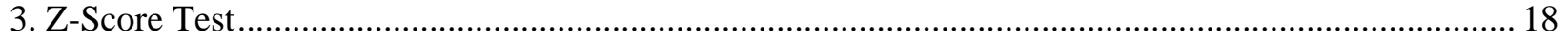

Boxes

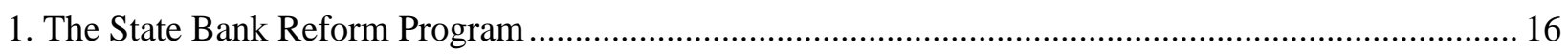

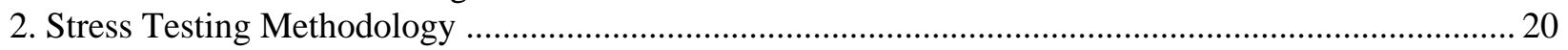

Appendixes

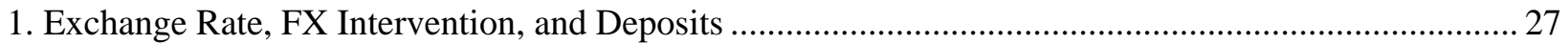

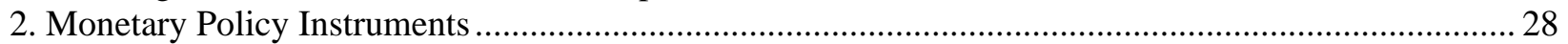

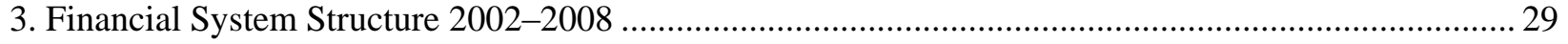

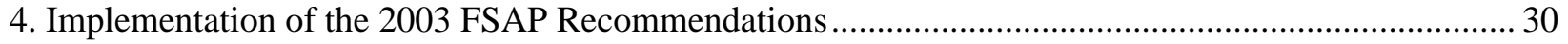

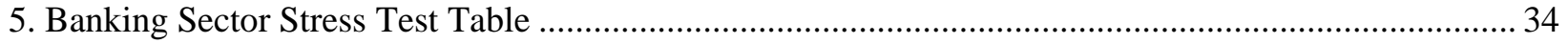

6. Observance of Financial Sector Standards and Codes: Basel Core Principles for Effective

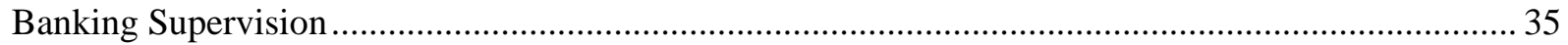

7. Bangladesh: Financial Stability Diagnostic and Assessment Matrix for FSSAs............................... 43

Tables

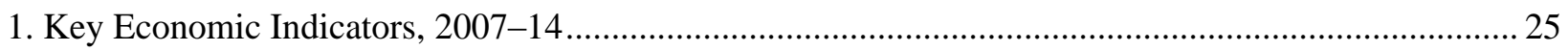

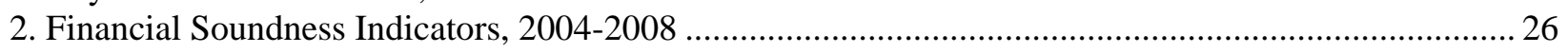




\section{GLOSSARY}

AML/CFT

$\mathrm{BB}$

BCA

BHBFC

CDBL

CEO

CIB

CRR

CSE

DIS

DPS

DSE

FCB

LOLR

MFI

MOF

MOP

MRA

SCBS

NGO

NIMA

NIR

NPL

NSS

ROE

RTGS

SBs

SCBs

SDB

SEC

SLR

SOE
Anti-Money Laundering/Combating the Financing of Terrorism

Bangladesh Bank

Banking Companies Act of 1991

Bangladesh House Building Finance Corporation

Central Depository of Bangladesh Limited

Chief Executive Officer

Credit Information Bureau

Cash reserve requirement

Chittagong Stock Exchange

Deposit Insurance System

Depository Pension Scheme

Dhaka Stock Exchange

Foreign Commercial Banks (branches of foreign banks)

Lender of Last Resort

Microfinance Institutions

Ministry of Finance

Ministry of Planning

Microfinance Regulatory Authority

National Commercial Bank

Nongovernmental organizations

Net interest margin to assets

Net international reserves

Non-performing loan

National Savings Scheme

Return on equity

Real-time-gross settlement

State-Owned Specialized Banks

State-Owned Commercial Banks

Specialized Development Bank

Securities and Exchange Commission

Statutory liquidity requirement

State-Owned Enterprise 


\section{OVERALl ASSESSMENT, STABILITY AND DEVELOPMENT ISSUES}

The Bangladesh authorities have strengthened the soundness of the financial system since the 2003 FSAP. Against the backdrop of improved macroeconomic performance, the financial system has grown rapidly. Considerable progress has been made in strengthening the resilience of the country's financial sector. Total assets of the banking sector have increased twofold since 2003 and credit to the private sector has risen threefold. Private domestic banks now hold a majority of banking assets, and the role of state-owned commercial banks (SCBs) and specialized banks (SBs) has correspondingly declined. Banking sector penetration has been enhanced and branch networks have expanded. Non-performing loans (NPLs) have decreased steadily since 2003 and the stated capital position of banks has improved.

Despite some progress, the supervisory system falls short of international standards and significant risks and vulnerabilities still exert pressure on financial sector stability:

- Loan classification, provisioning, and even capital remain uneven in the banking sector, creating potential vulnerabilities. Many of these weaknesses are concentrated in the SCBs and SBs. Non-prudential government intervention, such as interest rate ceilings, moral suasion, the potential for regulatory forbearance, and government orders to direct credit and ease debt service for some sectors, increases risks, reduces transparency, and creates inefficiency. SCBs' and SBs' management and boards have improved but need further improvement in technical and financial skills.

- The rapid growth in nontraditional banking activities in recent years is generating new risks, underlining the importance of strengthening the regulatory framework. Banks are rapidly increasing their engagement in capital market activity, directly or through merchant banks and brokerage subsidiaries. Risks to capital from a fall in the market could be large for some banks. Banks also have increased exposure to microfinance institutions (MFIs). MFIs are expanding into areas traditionally reserved for banks while managerial and regulatory capacity seems to be lagging. Although some of these changes reflect desirable innovation and growth of the financial sector, they partly reflect differences in the regulatory and tax environment. These changes create future vulnerabilities and raise potential risks for financial institutions' capital bases and, ultimately, the economy as a whole. There is scope to expand the regulatory perimeter to include unregistered MFIs.

- Supervisory agencies need to be improved and be ready to deal with the changing environment. Staffing needs to be reinforced and better efforts made to train and retain an expert cadre of professionals. It would be desirable to clarify banks' allowable activities and buttress regulation and its supervisory enforcement aimed at improving capital and provisions and limiting excessive risks, particularly with regard to banks' direct and indirect involvement in the capital market. MFIs' roles also should be clarified, and their regulatory regime strengthened through greater powers and capacity building for the Microfinance Regulatory Authority (MRA). 
- Basic stress tests on the commercial banks suggest that credit risk continues to be a particular concern. Exchange rate risk does not present a major risk in Bangladesh because the net open position of many banks is minimal. Financial soundness indicators are generally favorable, although the quality of the commercial loan portfolio remains weak, with a large share of loans classified in the substandard and doubtful categories. Stress test results suggest that commercial banks would be resilient to a moderate economic downturn, but SCBs and SBs would require capital injections under more severe conditions. Since the country relies heavily on the export sector, a slowdown in economic activities would have a direct effect on banks' asset quality.

The corporatization and reform of the SCBs has led to major improvements. The corporatization of SCBs in 2007 brought them under the regulatory authority of the Bangladesh Bank (BB), strengthened their boards and management, and upgraded their operations through a monitorable reform program that also reduced their NPLs. Capital was notionally boosted through a purely accounting transaction that increased goodwill by the amount of the SCBs' accumulated losses, although that goodwill is being gradually replaced by pre-tax, retained earnings of the SCBs. Although the SCBs' finances improved, they remain much worse than the private banks.

The securities market, an important component of a robust financial system, has experienced rapid growth but remains small and underdeveloped. The legal and regulatory framework for the securities market is adequate, but enforcement is lagging, in part due to the shortage of resources of the securities regulator, which needs to be addressed urgently. Work should continue on development of a secondary market in government bonds, and the corporate debt market could be complemented with the development of the commercial paper market.

In the last few years, the authorities undertook a series of reforms of the supervisory and prudential framework. Nevertheless, the financial system continues to be hampered by the fragile institutional and operating environment that is contributing to poor performance and has often triggered solvency issues. Moreover, the liberalization of the banking system and entry of new banks has not yet translated into efficiency gains due to the continued importance-albeit declining — of SCBs, which are not yet fully operating on a commercial basis. Further strengthening is needed in the following areas:

- improvement the implementation of accounting rules, loan classification, supervisory and provisioning requirements, which are still not up to international best practices;

- stricter enforcement of prudential regulations - to ensure full and accurate disclosure of banks' capital, NPLs, and other prudential indicators;

- strengthen credit information and the legal framework for finance, both of which remain well below international best practices, hindering loan quality;

- the reform program of the SCBs needs to continue to improve efficiency, governance, and reduce vulnerabilities, with the eventual goal of divesting government ownership of banks. 


\section{SUMMARY OF FSAP UPDATE RECOMMENDATIONS}

Priority Recommendations

\section{Banking Sector Stability Analysis}

Continue improving information collection and the use of the stress testing methodology.

Integrate stress test analysis with the supervisory function.

Replace interest rate ceilings, moral suasion, and directed credit with market-based incentives

Banking Sector Risks and State Owned Banks

Strengthen bank capital in line with banks' risks in the equity markets.

Continue the reform of state-owned banks with monitorable targets and a plan for eventual divestiture.

Establish a plan for improving the specialized development banks.

\section{Crisis Management and Safety Net Arrangements}

Introduce a lender of last resort facility to provide liquidity to solvent banks at a penalty rate.

\section{Monetary Policy Implementation}

Transform the repo/reverse repo into standing facilities and introduce a short-term ( 7 to 14 days) repo/reserve auction. Manage the market interest rate in the corridor defined by the repo/reverse repo.

Enlarge the time horizon of liquidity forecasting to match the reserve requirement maintenance period.

Scale down the use of the statutory liquidity requirement.

\section{Financial System Oversight}

Continue to strengthen BB by automating its operations, improving supervisory capacities (including more effective risk-based supervision), increasing transparency, enhancing disclosure policies, and providing it with greater independence and autonomy.

Improve assessment of banks' risk profile, management and governance and develop a clear, monitorable program for improvement in these areas.

Establish a framework for bank participation in merchant banking and brokerage activities through legally separate entities.

\section{Equity Markets}

Provide the SEC with greater autonomy in budget and personnel decisions and rules enforcement.

Set up a committee of stakeholders to develop a roadmap for demutualization of stock exchanges.

Near Term: 6-12 months; Medium Term: 12-24 months.
Near Term

Timeframe

Near Term

Near Term

Medium

Term

Near Term

Near Term

Near Term

Near Term

Near Term

Near Term

Near Term

Near Term

Near Term

Near Term

Near Term 


\section{MACRofinancial ENVIronMEnT}

1. Macroeconomic performance in Bangladesh has been buoyant in recent years, despite natural disasters and volatile food and energy prices. Strengthened policy frameworks and macroeconomic fundamentals along with limited openness of the economy-in particular, with respect to short-term capital flows - and resilient export and remittance flows have bolstered growth and external stability, and sheltered the financial system and nonfinancial corporates from external shocks. External debt is sustainable and largely concessional; international reserves are strong (Appendix 1 Table 1).

\section{A. Recent Financial Sector Developments}

\section{Bangladesh's financial sector has been resilient to the unfolding global financial}

turmoil. As a result of current foreign exchange (FX) regulations, banks have low exposures to FX structured products and credit derivatives - with the exception of some forward contracts. Off-balance sheet activities are typically basic swap contracts, which—given the negligible trading volume - do not create significant exposure to unexpected losses. There is little evidence that external shocks have increased the risk of asset quality problems or precipitated a credit crunch. However, a "third wave" of the global crisis - possibly involving slowing exports and remittances—still poses risks.

\section{Legal and regulatory reforms and liberalization measures in the $1990 \mathrm{~s}$ - in} particular, the partial liberalization of interest rates and the increasing share of private banks-have contributed to the strengthening of the financial sector. These reforms combined with robust economic growth, strong agricultural performance, and lower inflation helped to boost the profitability of banks and lower NPLs, most notably in 2008 (Appendix 1, Table 2). Although the banking sector's assets are equivalent to 65 percent of GDP (Appendix 3), the sector remains structurally weak, reflecting low capitalization, provisions, and distortions due to weak and systemically important SCBs and SBs. The nonbank financial sector remains underdeveloped compared to most countries, except for the MFI sector.

4. The major potential macroeconomic risks arise from remittances, export earnings, commodity prices, and excess liquidity in the banking system. Although remittances have held up - with growth of 22 percent in the just-ended fiscal year - the recent fall in the number of workers leaving the country poses a risk for the future. Strong export earnings performance is attributable to shifts in demand in major export markets to the lower-end garments that Bangladesh produces. Looking forward, rising commodity prices could erode the recent improvement in the balance of payments, while high excess liquidity arising from unsterilized interventions could lead to inflationary pressures and credit risk (Appendix 7). 


\section{Figure 1. Bangladesh: Recent Economic Developments}

Remittances reached almost 11 percent of GDP in FYO9

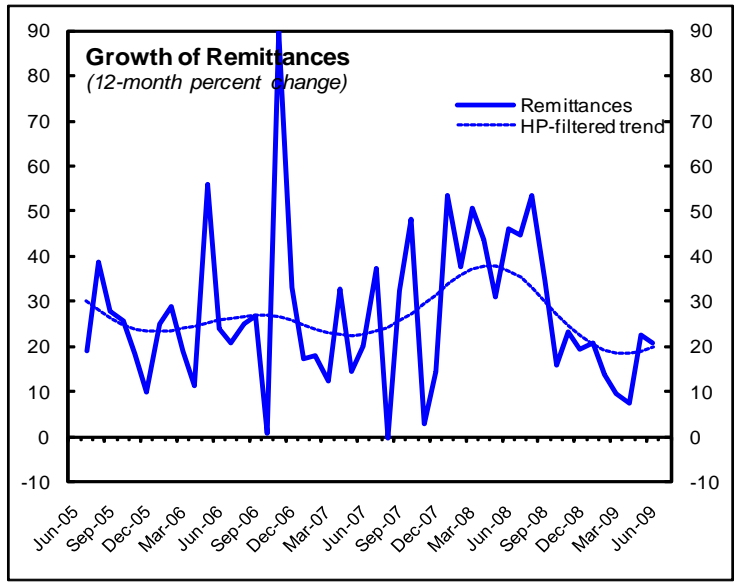

Central bank reserves have risen sharply in recent months

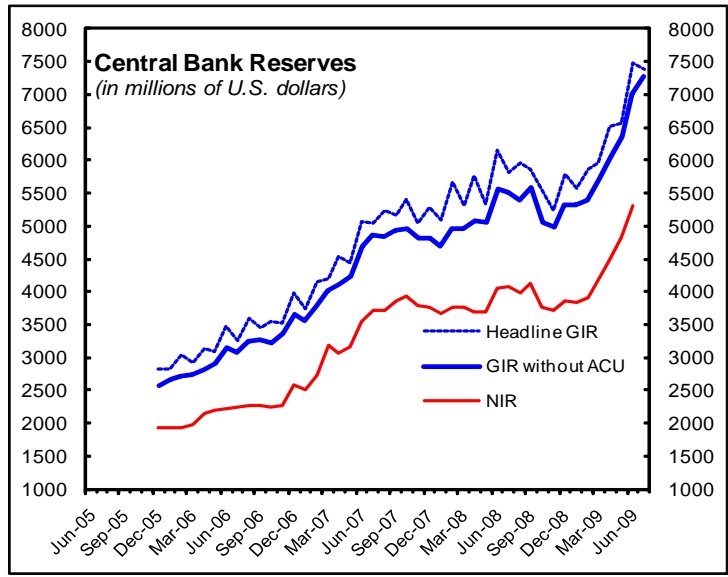

The lending spread remains in excess of 5 percent

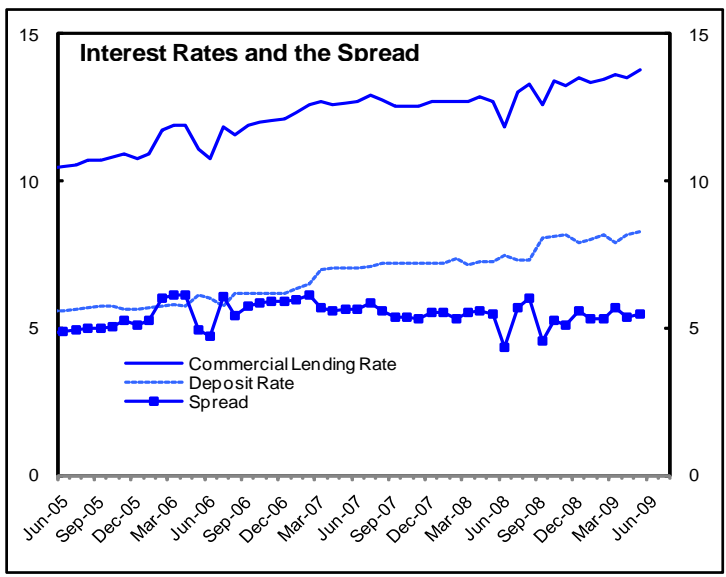

The current account surplus has grown

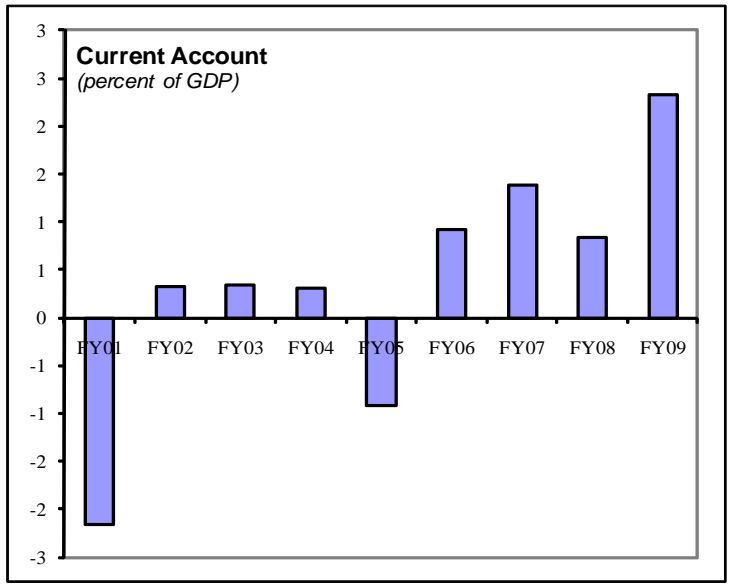

Commercial banks also accumulated foreign exchange

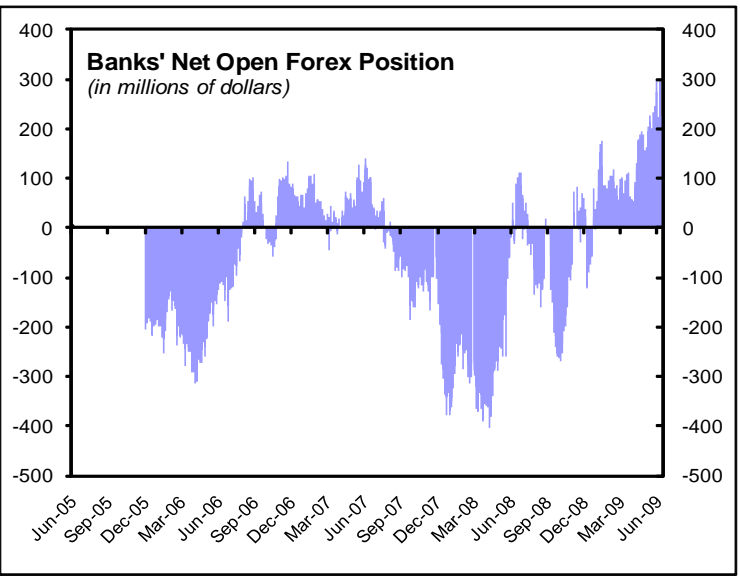

Growth has remained robust

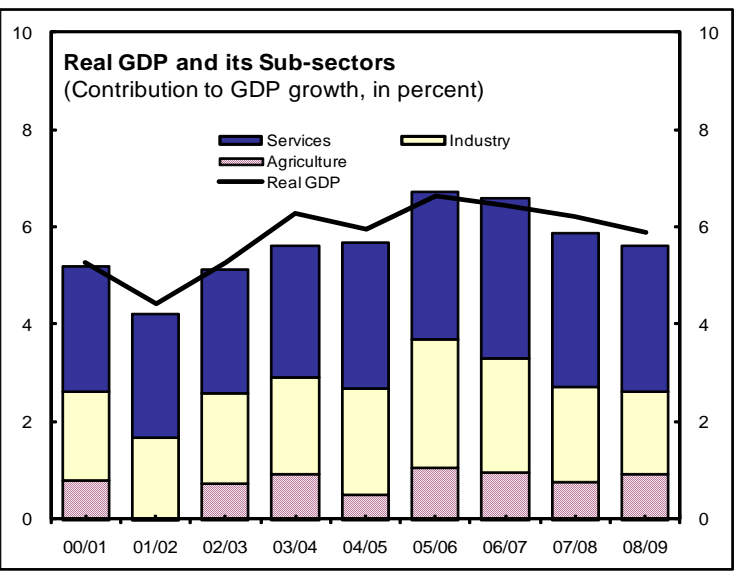


5. Some risks for the stability of the macroeconomy and the financial system are arising from the strong position of Bangladesh's balance of payments and the monetary and exchange rate frameworks. Unsterilized intervention aimed at keeping the exchange rate stable has led to excess liquidity and has pushed down short-term interest rates. Persistent excess liquidity (Figure 2) may eventually turn into a credit boom, rising equity prices, and inflationsuch as of housing prices. Some banks have increased their dependency on short-term, wholesale funding, exposing themselves to liquidity risk.

\section{B. Monetary Policy Framework, Liquidity Management, and FX Operations}

6. A revised central bank act is currently being reviewed. A focus group considered a revised central bank act in 2007 and recommended to: (i) officially give autonomy to BB; (ii) simplify the monetary policy objective to price and financial sector stability; (iii) install a monetary policy committee to design BB action, and (iv) introduce a LOLR facility. BB is expected to play the role of government agent although its advances to the government are limited to a three-month term and their cost is linked to the T-bills market rate. The suggestions of the focus group would be significant improvements from the 1972 central bank act if implemented.

7. The potential volatility of short-term funding conditions is a risk to the stability of the financial sector in Bangladesh. The recent surge in liquidity in Bangladesh created opportunities for maturity mismatches, especially as banks increasing funded themselves in the call market (Appendix 2). The uncollateralized overnight money market (call market) is vibrant with an average turnover of about Tk50 billion (1 percent of the GDP). BB should consider introducing an interest rate corridor in order to establish a minimum (reference) rate in the market, and to provide a greater assurance of stability in this increasingly important market.

8. BB prepares liquidity projections on a four-day basis. Over this short period, the quality of the projection is rather good, but would likely decrease rapidly if the forecasting horizon were to be extended. The Ministry of Finance does not provide its cash flow projection to the section of BB in charge of liquidity projection, complicating the estimation of the government position. In addition, the stability of the exchange rate (Figure 2) suggests that the central bank reacts to foreign exchange market pressures, and makes BB's interest rate projection less accurate. ${ }^{1}$

\footnotetext{
${ }^{1}$ The exchange rate arrangement is classified as "stabilized" in the IMF (de facto) classification. However, the authorities consider that their exchange rate arrangement is a managed float with intervention limited to deal with undue fluctuation of the exchange rate. In fact, the taka has been very stable against the U.S. dollar since 2006 against the backdrop of regular and sizeable interventions of the central bank. The turnover on the foreign exchange market is 11.8 million U.S. dollars per day on average since January 2009, which represents less than 1 percent of the GDP. During the same period, the average daily intervention has been 7 million U.S. dollars a day. The development of the forward and swap markets remains subdued with few transaction completed since 2006.
} 
9. The foreign exchange regulations control the capital account of Bangladesh.

Although foreign exchange regulations leave most current account transactions free, export earnings have to be partially surrendered to authorized dealers. ${ }^{2}$ The surrender requirement ratio is determined by the import financing needs of particular sectors. Worker remittances may be kept in their owner's foreign currency accounts in a domestic bank. However, foreign exchange remitted to someone else, such as a family member, has to be surrendered to authorized dealers. Resident investment abroad requires BB's prior approval. Regulations specific to banks include: (i) prior approval of $\mathrm{BB}$ for local lending in foreign exchange; (ii) control over interest rates on foreign exchange deposits; and (iii) a limit on banks' net open position-recently relaxed to 15 percent of banks' capital.

\section{As a result of the capital controls, the foreign exchange denominated assets and} liabilities of the banking system, including foreign exchange related derivatives, are low. In particular, FX denominated loans by the banking system are 0.4 percent of bank loans, and are mainly provided for external trading purposes. FX denominated deposits are only 1.8 percent of deposits and represent mainly deposits by foreigners.

Figure 2. Bangladesh: Excess Liquidity and the Money Market, 2005-2008
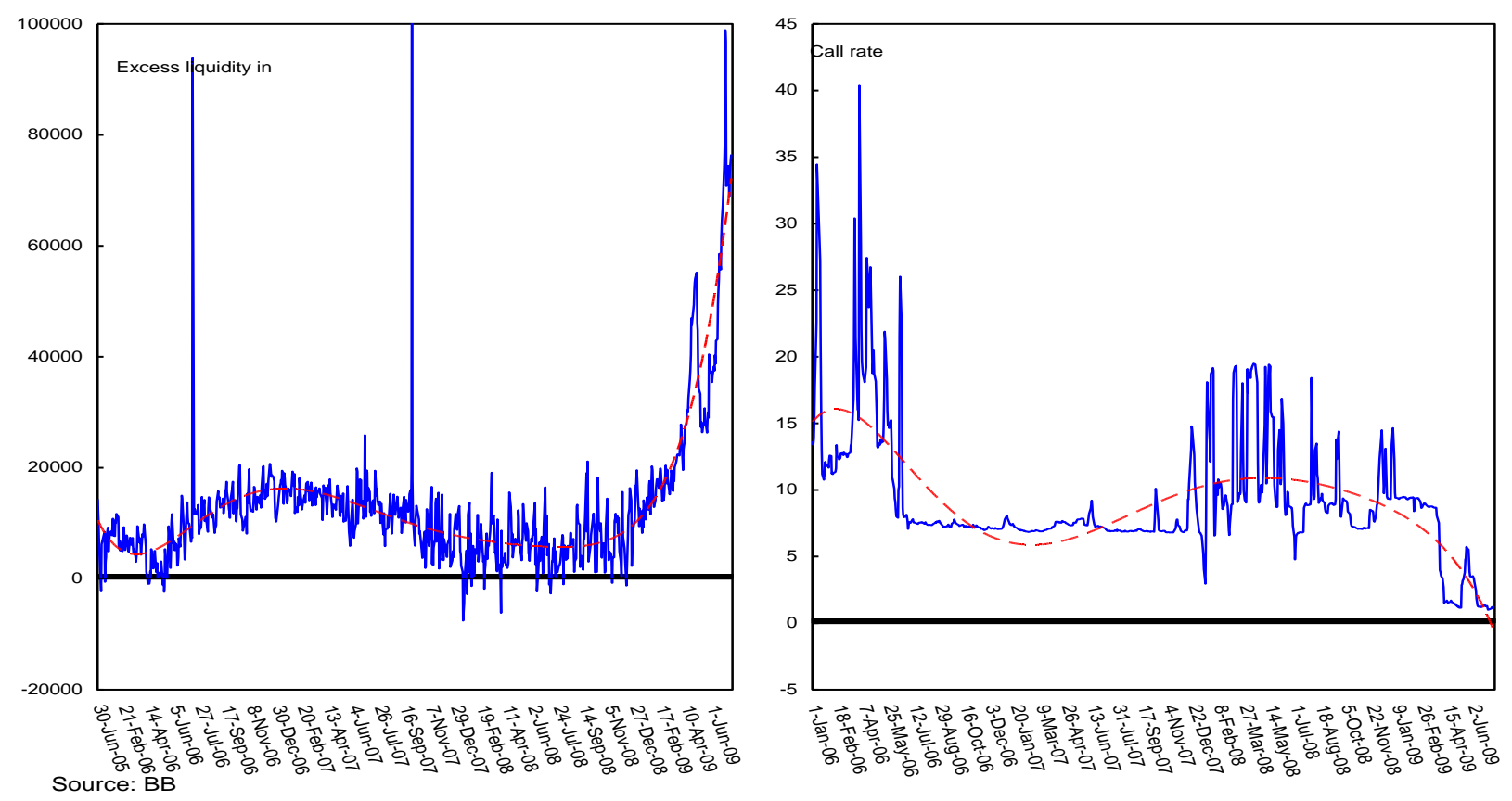

\footnotetext{
${ }^{2}$ Except for the transfers abroad of nonresident income related to rents. This restriction was introduced to avoid capital flight.
} 


\section{The BANKING AND Other FinANCIAL SECtorS}

\section{The banking sector has made progress since the last FSAP in 2003. The financial} system has grown rapidly and private domestic banks now hold a majority of banking assets. The roles of SCBs and SBs have correspondingly decreased. Banking sector penetration in the economy has increased and branch networks have expanded. NPLs-which had been high under the influence of weak standards of corporate governance, underdeveloped risk management systems, and directed lending-have decreased and the stated capital position of banks has strengthened.

\section{Nevertheless, significant and long-standing risks and vulnerabilities remain within} the banking system. Loan classification, provisioning, capital, and bank management and governance remain uneven in the banking sector, creating potential vulnerabilities. Nonprudential government intervention, such as interest rate ceilings, moral suasion, directed credit and explicit requirements to ease debt service for some sectors of the economy, increases risks, reduces transparency, and creates inefficiencies.

\section{A. Financial Structure and Bank Ownership}

\section{The financial system has grown substantially since 2001 and remains dominated by} the banking sector. Banking penetration has increased and stock markets and MFIs have become more important. Bank assets are now equivalent to 62 percent of GDP compared to 47 percent in 2001 (Appendix 3). However, the number of banks has remained roughly constant since 2002 reflecting the government's policy of not issuing new bank licenses. Nonetheless, the banking sector is becoming more competitive and responsive to client demand for better service. Outside the banking system, the ratio of equity market capitalization to GDP has grown to about 14 percent at the end of 2008, compared to 2 percent in 2001, while listings have increased by nearly 30 percent. A government bond market is developing, but the corporate bond market does not really exist. MFIs, which are subject only to limited regulation and are untaxed, have grown rapidly; their loans are now equal to 3 percent of GDP. In addition:

\section{- Private domestic banks now own 55 percent of bank assets, compared to 35 percent in} 2002 (Appendix 3). Private banks' growth has been funded by rapid deposit growth; foreign borrowing is not permitted. The largest Islamic bank's growth has benefited from its handling of Bangladesh's rapidly growing remittances. Private banks' retail credit growth was limited until recently. ${ }^{3}$ Equity-market related loans have increased substantially recently. Instead, the main sources of private banks' growing asset share were rapid increases in traditional trade and working capital lending as well as increased term loans to industry and lending to larger agricultural firms and SMEs.

\footnotetext{
${ }^{3}$ The initial slow growth of such consumer credit may reflect the regulatory stance earlier in the decade and the high (5 percent) general provision for such consumer credit.
} 
- The private domestic banks' expansion came, mainly, at the expense of the SCBs. The SCBs lost market share due to: (i) weak balance sheets that would not support rapid credit growth; (ii) slow growth of SCBs' traditional borrowers; (iii) relatively high NPLs; ${ }^{4}$ and (iv) their unresponsive business processes. In addition, loan growth of all SCBs was limited administratively while awaiting privatization. The market shares of foreign banks and specialized development banks (SDBs) have not changed much.

\section{Financial intermediation by banks and MFIs has deepened significantly in recent} years, particularly bank intermediation. Bank deposits are now over 50 percent of GDP, having risen from 30 percent of GDP in 2001. Bangladesh's deposit-to-GDP ratio is large given its per capita income and comparable to its South Asian counterparts (Appendix 1 Figure 1). MFIs' assets have doubled since 2001 (Appendix 3).

15. The capital market is underdeveloped and equity oriented while the debt securities market is still at a nascent stage. The market capitalization of listed companies was about 14 percent of GDP at the end of FY08. ${ }^{5}$ The debt securities market in Bangladesh is very small, accounting for about 17 percent of financial system assets in 2006. Government debt securities overwhelmingly dominate the market but nonmarketable, national savings certificates account for an even larger share (more than three-fifths) of debt instruments. ${ }^{6}$ The corporate bond market remains largely undeveloped. Long-term financing is scarce, which impacts on infrastructure financing, especially power investment and housing investment.

16. The housing finance sector is underdeveloped, though growth is underway. Housing finance is expensive and rationed in favor of salaried employees with relatively high incomes. The Bangladesh House Building Finance Corporation (BHBFC) that has traditionally dominated the housing finance sector is now a spent force due to: (i) decreasing government support and (ii) operational ineffectiveness. Housing finance also suffers from weaknesses in the legal execution of collateral and enforcement of mortgage contracts.

\section{The public Credit Information Bureau (CIB) suffers from several shortcomings} including lengthy and manual operational processes. Improvements are needed to improve credit information, the quality of bank lending, and access to credit. The absence of reputable credit rating companies in Bangladesh puts additional pressure on the local rating agency, which is still in the process of establishing its credibility and acceptance.

\footnotetext{
${ }^{4}$ Borrowers with NPLs recorded in the Credit Information Bureau cannot borrow.

${ }^{5}$ Dhaka Stock Exchange (DSE); the Chittagong Stock Exchange (CSE), where the same stocks are traded, had a capitalization of $\$ 11.3$ billion.

${ }^{6}$ Government securities began trading at DSE from January 01, 2005. Treasury bonds of 5- and 10-year maturities were issued in 2003, and secondary trading of T-bills among the banks was also introduced recently.
} 
18. Investment funds are becoming a more common vehicle for the mobilization of term finance for infrastructure projects. Banks alone are not well suited for the purpose, given their reliance on short-term deposits and the limited capital they have to absorb risk. Further, investment funds are supported by and also spur the evolution of the contractual and collective investment schemes, capital markets, and institutional investors. In order to stimulate infrastructure development, a virtuous circle needs to be created involving encouragement of public-private partnership policies, a conducive legal framework, and the necessary financial vehicles and markets, in a concerted and holistic effort.

19. The initial FSAP identified a range of weaknesses and vulnerabilities across sectors, notably highlighting that the financial system was poorly developed and its banking sector was weak (Appendix 4). It argued that Bangladesh's development had been constrained by poorly defined and enforced property rights. The 2003 FSAP also noted that the capital market was small and stagnant, insurance was characterized by overcrowding of small companies and ineffective regulation and supervision, and housing finance was severely constrained by high interest rates and weak enforceability of mortgage collateral. ${ }^{7}$ Other limitations included distortions created by the subsidized state-owned real estate lender (BHBFC) and flaws in the property titling and registration systems.

20. In the last few years, the authorities undertook a series of reforms of the supervisory and prudential framework. Nevertheless, the financial system continues to be bogged down by the fragile institutional and operating environment that is contributing to poor performance and has often triggered solvency issues. Moreover, the liberalization of the banking system has not yet translated into efficiency gains due to the continued importance, though declining, of large, weak state banks that are not operating on a commercial basis. Further strengthening is needed in the following areas:

- improvement of accounting rules, loan classification, supervisory and provisioning requirements — which are still not up to international accepted practices;

- stricter enforcement of prudential regulations - to ensure full and accurate disclosure of banks' real capital, NPLs and other prudential indicators;

- strengthened credit information and the legal framework for finance, both of which remain well below international accepted practices and hinder credit expansion and loan quality;

- continued improvements in the efficiency and governance of the reform program of the SCBs with the eventual goal of reducing state control of institutions;

\footnotetext{
${ }^{7}$ Recognizing the need to better regulate the insurance sector, the authorities have recently introduced two bills (Insurance Regulatory Authority Bill of 2009 and Insurance Bill of 2009) to allow for an independent regulatory authority to monitor the insurance industry and also raise the minimum paid-up capital requirements for insurance companies.
} 
- clarified roles of SBs with respect to their policy objectives and their commercial activitieswith the aim of improving governance and performance.

\section{B. Banking System Performance and Vulnerabilities}

\section{Performance of the Banks: Capital, NPLs, Income, and Profits}

\section{Commercial banks' performance has improved on average, in the context of} continued rapid GDP growth, strengthened prudential regulation, and recent efforts to improve the SCBs. The reported average capital ratio is now about 10 percent of risk-weighted assets, roughly equal to the new minimum standard. ${ }^{8}$ Reported classified assets are down compared to 2007, although they still represent a large 10.8 percent of loans (under 5 percent for private and foreign banks). NPL ratios have been declining continuously since 2001 across all banks, albeit from a very high level. ${ }^{9}$ Coverage of required provisions by SCBs has improved though it remains less than 100 percent for private banks on average. It should be noted that provisions are low by international standards, ${ }^{10}$ and delinquent loans can be rescheduled as performing on payment by the borrower to the lending bank of a fee set by BB. In particular, the current loan classification poses significant risks to the banking sector as it delays recognition of credit risk. ${ }^{11}$

\section{Average returns on assets and equity have increased for all types of banks, though} they still appear low by international standards and may indicate some risks. Private and foreign banks earn higher rates of return than SCBs reflecting better loan origination and greater participation in equity trading and activities related to the equity market. The dependence of returns on the recent rise in activities in the equity market indicates risks in the banking sector.

\footnotetext{
${ }^{8}$ Commercial banks are expected to have a minimum 10 percent CAR, 5 percent of which must be tier 1 capital. These ratios were increased from 9 percent and 4.5 percent in 2007. Tier 2 capital includes a general provision of 1 percent for all unclassified loans except for: (i) housing and SME lending (2 percent) and (ii) consumer credit and special mention loans (5 percent). High bank taxes (45 percent compared to 35 percent for industrial firms) also deter internal equity accumulation.

${ }^{9}$ Average NPLs have dropped from 41 percent to 10.8 percent of assets from 2001 to 2008 owing to rapid growth of GDP and credit. The provisioning ratio over total assets decreased in the same period to 3.8 percent. From a risk classification perspective, the asset quality of the commercial loan portfolio remains weak. Liquid assets cover only 29.4 percent of liquid liabilities.

${ }^{10}$ Specific provisions of 20 percent are required for non-term loans after debt service is overdue for 6 months, 50 percent after 9 months and 100 percent after 12 months. However, term loans, and especially loans to agriculture and SMEs, all of which weigh more heavily in the lending of SCBs and SDBs, allow for much longer periods of debt service delinquency before provisions are required.

${ }^{11}$ Currently, a loan is classified as 'Sub-standard' if it remains past due/overdue for 6 months-or beyond-but less than 9 months; as 'Doubtful' if past due/overdue for 9 months-or beyond-but less than 12 months, and as `BadDebt' if past due/overdue for 12 months-or beyond. Borrowers can be rescheduled as performing, according to BB rules, if they pay a set fee (10 percent of the outstanding debt for the first rescheduling).
} 
The potential volatility of the market represents a risk that the market could fall and impinge on asset values substantially. To contain this risk, additional capital should be allocated to value at risk in the market, as required under Basel II; banks' risk management of these activities should be improved; and consolidated supervision of them — including banks' new subsidiaries — should be strengthened. ${ }^{12}$

\section{SBCs have made progress, especially in reducing NPLs, but their capital remains} low even after notional goodwill creation (Box 1). The SCBs' recent reduction in NPLs largely reflects the results of the Government's restructuring program, supported by the World Bank and monitored by BB. The program focused on recovery of NPLs and management improvement along monitorable lines, but it is set to close at the end of 2009. However, the loss category NPLs still exceeded the restated equity position of SCBs, thus implying their technical insolvency. The SCBs' past NPL problems reflect not just the SCBs' ineffective procedures for identifying borrowers, poor risk management, and weak collection of debt service, but pressures to make loans and limit debt service payments in certain sectors. Moreover, the 2007 addition to goodwill is more than double the book value of capital. However, this addition to capital will be amortized over the next 10 years by SCB profits. ${ }^{13}$

\section{Interest rate ceilings, moral suasion, and directed credit generate inefficiencies and}

vulnerabilities. BB has instituted interest rate ceilings in the hope of ensuring low cost credit to certain sectors. Furthermore, the Government has also tried to ensure the availability of funding and reduce debt service for some sectors through moral suasion and SCBs' lending, thus affecting banks' efficiency and contributing to the poor performance of the state banks. In particular: (i) interest rate ceilings force banks to provide loans only to the most creditworthy customers, thus depriving other borrowers from funds and affecting banks' profitability; and (ii) directed credit forces banks to provide credit to inefficient segments of the market, which, usually, fail to service their debt, thereby leading to higher NPLs, inefficient resource allocation, and slower growth. The banking system and the economy would function more efficiently and transparently if credit were allocated by the banks under stronger prudential regulation on the basis of market-based incentives.

\footnotetext{
12 The authorities noted in their comments that capital charges on market risk exposures have been introduced with the implementation of Basel II capital standards and on-site supervision examinations include assessing the processes and practices of market risk management in the banks. Also, consolidated supervision will be considered for those banks engaging in capital market operations through subsidiaries.

${ }^{13}$ The Specialized Development Banks (SDB) continue distorting the market with subsidized loans. Their lax loan recovery policies have negative consequences on the lending culture as a whole and burden the government's budget. One exception is Basic Bank, which seems to be providing a reasonable service to SMEs.
} 


\section{Box 1. The State Bank Reform Program}

Under the reform program, SCBs have raised their capital to 10 percent on average, (excluding the worst SCB).

The four SCBs were corporatized into LLCs owned by a government holding company in 2007. The corporatization brought the SCBs under BB's regulatory authority, coupled with a notional accounting increase of Taka 87.9 billion in goodwill/capital, equivalent to the SCBs' accumulated losses. The SCBs are committed to use pre-tax "amortizations" to replace this notional capital increase over 10 years, and the 2008 "amortizations" have been made. This procedure reduces reported earnings from the SCBs.

In 2007, the government began a restructuring of three of the SCBs to operate along more commercial lines, which was monitored by BB and supported by the World Bank. CEOs/MDs and four General Managers (Accounting, Audit, IT and HR) were selected competitively and remunerated at private sector levels based on performance. Annual, monitorable goals were set for cash recovery of NPLs, limits on new NPLs, operations, computerization, profitability, increased net worth, and disclosure. These goals were almost wholly achieved in 2008 and mostly seem on target for 2009. The average capital of these banks is now 10 percent. Voluntary retirement schemes are being formulated to reduce staff but will require approval of the Ministry of Finance. The banks have also been engaged in long-term planning, which will involve a careful consideration of the profitability of individual branches.

Rupali Bank, the fourth SCB was targeted for privatization even before 2007, but the privatization did not succeed leaving the bank's position unresolved. The bank was an LLC before 2007 with a small share of equity held in listed shares. Its major activities were suspended for over two years awaiting the privatization, which fell through in 2008. In the meantime, the bank's operations and financial condition deteriorated significantly. The bank was added to the restructuring program, but its management was not changed as was done in the other SCBs. Although its performance improved somewhat, it generally failed to meet its targets. In addition, the bank's finances could further deteriorate owing to its unsecured exposures to state-owned enterprises.

Despite the gains, SCBs' finances remain weak and ad hoc government demands put an additional stress on profitability. For instance, the government pressured banks to open low return L/Cs for petroleum, fertilizer, and food during the oil/food price run-up. Furthermore, the government's moral suasion and targets for various types of lending decrease profitability - potentially more so than for PCBs. In addition, the SCBs, like all banks, may suffer lower returns due to the recent ceilings on lending rates. Required assurances for SCBs not to engage in excessive, non-profitable lending are not yet in place.

25. The regulation of microfinance is weak, creating potential future vulnerabilities. MFIs are regulated and supervised by the Microfinance Regulatory Authority (MRA). Licensing and ongoing supervision are ineffective given both the lack of resources and the approach. As MFIs are small, this in itself does not pose risks to the financial system. However, banks are opening microfinance units. Hence, the border between the regulated banking sector and the largely unregulated microfinance sector is increasingly porous. ${ }^{14}$

\footnotetext{
${ }^{14}$ Stricter regulations and supervision practices-closer to those applicable to banks-should be considered for larger MFI. In this regard, it would also be advisable to revise regulations concerning taxation that applies to banks, MFIs, and cooperatives to reduce distortions and arbitrage. The deposit insurance scheme for MFIs-foreseen in the MRA
} 


\section{The state-owned commercial banks}

26. The situation of state-owned commercial banks strengthened under the government sponsored reform program but remains weak. The profits of SCBs remain lower than the profits of private banks because of the provisioning of their large NPLs and amortization of the goodwill addition to capital. The level of nonperforming loans was reduced by 4 percentage points in 2008, but still stands at 25 percent, five times the NPL ratio of private banks. Besides a tight monitoring of SCBs' activities, the authorities' reform plan reinforced their capital ratio to 10 percent. However, a significant part of the recapitalization was notional, made by adding a goodwill account. The situation of the SBs is even worse than that of the SCBs because they are generally under much greater pressure to provide loans on a directed credit basis to certain sectors.

\section{The authorities should contain the risks posed by the SCBs through a variety of} measures and, most especially, avoid un-funded demands for direct lending. These measures include: (i) continuing the reform program, which is about to expire, in particular the approach of monitorable targets and maintaining pay and incentives to attract and retain top quality management; (ii) improving the governance of the SCBs further with more independent and technically capable boards that are responsible for performance, and (iii) bringing Rupali Bank into the reform program. Perhaps, even most importantly, the government needs to avoid unfunded demands on the SCBs for directed lending, easing of debt service payments, and provision of services. In addition, the government will also need to establish a long-run plan for the SCBs and their role in the financial system, which may include their eventual conversion into private ownership, and ensure that actions taken, such as sale of minority ownership in the market, do not hinder achievement of the long run goals.

28. The analysis suggests a modest improvement in financial stability since 2003, but little change in the relative position of institutions. ${ }^{15}$ In particular, the average $\mathrm{Z}$-score of the system has improved somewhat since 2003 (Figure 3), but the same institutions that were fragile then remained so in 2008, except the state-owned banks. The SCBs, which had relatively high scores in 2003, suffered a drop in their scores by 2008 , reflecting a change in the accounting framework in 2006.

ordinance-should be implemented together with a framework for failing MFI. In addition, BB and MRA should consider strengthen capacity to supervise MFI.

${ }^{15}$ The Z-score measures the number of standard deviations a return realization has to fall in order to deplete equity - under the assumption of normality of banks' returns. As such, the Z-score can be thought of as a measure of resilience, i.e., higher Z-score implying stronger resilience to shocks. 
Figure 3. Z-Score Test

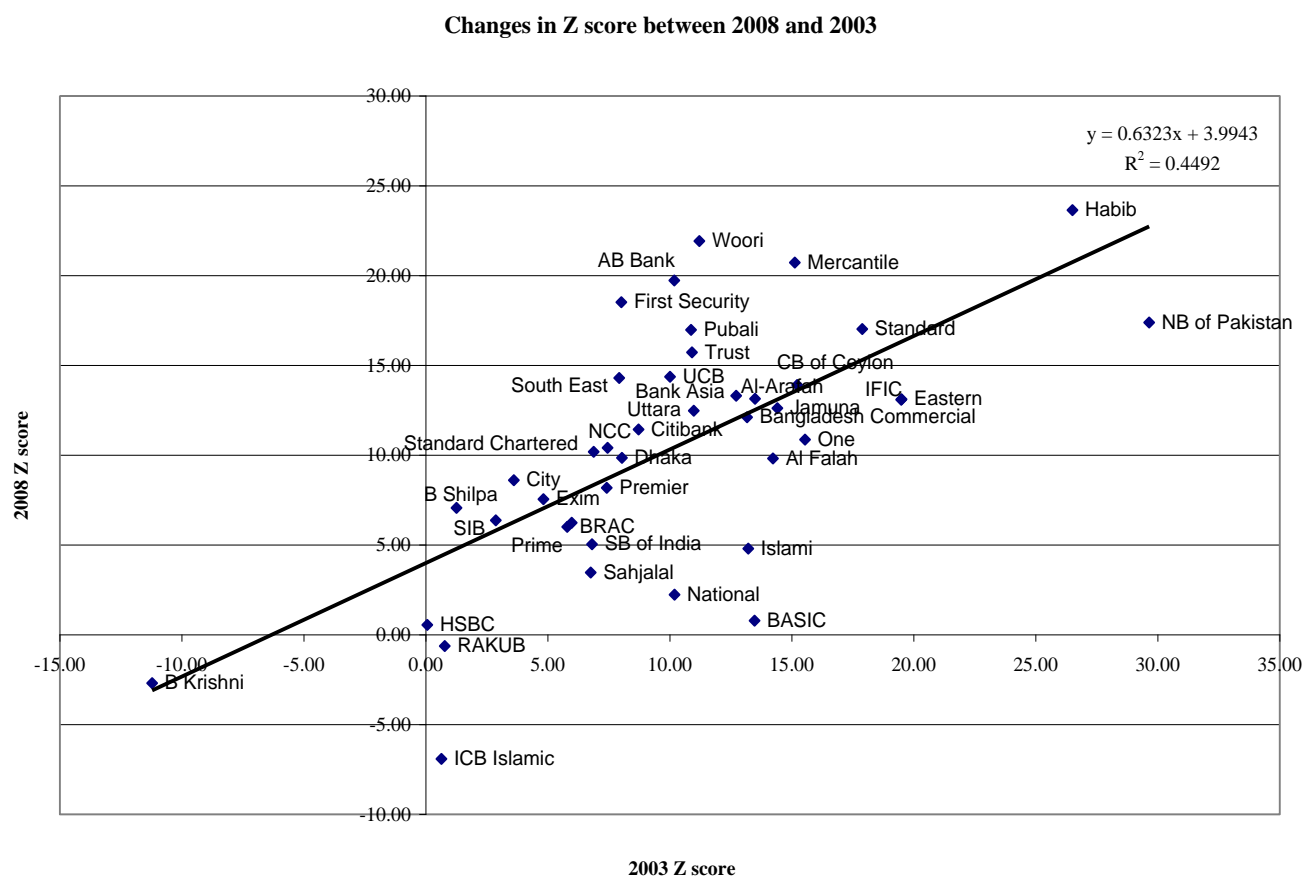

\section{Stress Test Results}

29. Stress tests were performed to assess the resilience of the banking sector. The intention was to analyze the impact that extreme, but plausible, shocks would have on the banking sector. ${ }^{16}$ In particular, the tests combined both single-factor sensitivity and scenario analysis (Box 2 explains the stress testing methodologies):

- The single-factor analysis allowed for various size shocks to be tested. Moreover, due to the current environment of excess liquidity, the analysis measured the resiliency of the sector in the wake of the impending second wave of a global slowdown that is anticipated.

- The macroeconomic scenarios allowed shocks of different risk factors all influenced by macroeconomic developments. Currently, the export sector (garment) maintains good growth due to the sector's specialization in lower end garments and the shifting of production to Bangladesh from elsewhere in Asia. In addition, remittance growth is moderating due to fewer employment opportunities abroad and a lower net outflow of workers.

\footnotetext{
${ }^{16}$ The tests were based on data provided by BB and other publicly available data. In designing the shocks, the analysis had to rely on past experiences, expert judgment and certain simplifying assumptions. Therefore, the results should only be treated as approximations.
} 


\section{Sensitivity analysis}

30. Analysis of the impact of a range of shocks, undertaken on a bank-by-bank basis, suggests that credit risk continues to have a larger impact than any other single factor. Shocks performed assumed a uniform 20 percent deterioration of the loan portfolio for top-down and bottom-up analysis (Appendix 6). The banking sector's CAR declined by 1.4 percent and would require Tk29 billion to meet the regulatory minimum of 10 percent. Additionally, when analyzing individual banks, five banks including two state-owned are currently below the CAR minimum. When the shocks were applied, three more banks fell below the minimum CAR. All nine foreign banks operating in Bangladesh were resilient. Exchange rate risk does not present a major risk in Bangladesh because the net open position of many banks is minimal. ${ }^{17}$

31. Scenario analysis was also used to assess Bangladesh's banking sector. Since the country relies heavily on the export sector-and the garment exports accounts for 75 percent of all exports - a slowdown in economic activity would have a direct effect on banks' asset quality. The sectoral distribution of loans is dominated by industry and trade, which are directly related to exports and to a lesser extent import of food. A scenario was assumed in which GDP declined by 1.5 percent - which is a plausible assumption given the behavior of the series for GDP in the last 15 years. Based upon a regression model, it was found that the proposed decline of GDP would have an effect on NPLs (20 percent), exchange rate (25 percent depreciation of the taka against the dollar) and interest rates (200bp decrease) due to the implementation of monetary policies consistent with a lower FX rate. The results indicated that 15 banks would fall below the regulatory requirements including all SCBs. The Development Finance Institutions (DFI) would essentially be insolvent. However the private and foreign banks would be resilient. Some foreign banks are creating risk management units and strengthening in-house capacity for stress testing.

\section{Financial development and intermediation}

\section{Financial intermediation has deepened significantly in recent years, particularly} bank intermediation. Bank deposits are now 53 percent of GDP, having risen from 42 percent of GDP in 2002. Bangladesh's deposit-to-GDP ratio is large given its per capita income and is comparable to its South Asian counterparts (Appendix 1 Figure 1). Bangladesh's deposit-to-GDP ratio is lower than Southeast Asian countries, but they have much higher per capita GDP. Despite Bangladesh's good performance in this area, it seems likely that over time the ratio of deposits will need to be further deepened and savings and investment increase, as has occurred recently in India, to achieve higher GDP growth.

\footnotetext{
${ }^{17}$ In analyzing exchange rate risk, it was assumed that the Taka would appreciate against the U.S. dollar by 5 percent.
} 


\section{Box 2. Stress Testing Methodology}

The stress tests performed included sensitivity and scenario analyses agreed with the authorities. The sensitivity analyses performed included, credit risk, market risk, and liquidity risk. The main idea was to build on the tests performed during the 2003 FSAP. The current update-covering the entire 48 banks operating in Bangladesh as of December 2008 — was conducted on the back of an environment of excess liquidity in the banking system stemming from record remittances that currently stand at about US\$10 billion. Also the NOP, although still small, has grown since 2004 by 40 percent.

The scenario analysis was to assess the impact macroeconomic indicators would have on the banks' credit and liquidity and to a lesser extent market risk.

- Credit Risk: Two main tests were done to gauge asset quality and concentration risk. In the former, a uniform deterioration of loan portfolios was assumed. This required provisions to be recalculated for each classification for the entire system and certain groups. A second test assumed a category shift in loan classification for each bank. This also required provisioning rates to be recalculated.

- Concentration Risk: The deterioration of assets was performed for the main economic sectors in Bangladesh: Industrial, Trade and Agriculture. We assumed that the second wave of the current economic crisis would impact Bangladesh's main sectors. The shock included a uniform increase in NPLs and its impact on CAR and provisioning rates. We also estimated the required injection of capital to meet regulatory standards.

- Market Risk: Both exchange rate and interest rate risk were analyzed. The shock to the exchange rate assumed an appreciation and depreciation of the Taka vis-à-vis the US dollar, which is the most traded foreign currency even though the EURO, Sterling Pound and other regional currencies are traded. The results are to examine the impact on CAR and FX induced credit risk. The interest rate shock included a parallel upward and downward shift in the yield curve and its impact on net income and CAR.

- Liquidity Risk: The test simulates a run on demand deposits. The test assumed a 20 percent run on demand deposits and its impact on the liquidity ratio.

- Scenarios Analysis: We assume a scenario of a decline in GDP due to a slowdown in garment exports, a tightening due to a decrease in excess liquidity in the market, and the result of a weatherrelated catastrophe on the agricultural sector.

33. Bangladesh also intermediates a reasonable proportion of its deposits to the private sector, equivalent to 37 percent of GDP. Credit to the private sector is a significant determinant of economic growth in Bangladesh, where the ratio of private credit to GDP is high for a country of its per capita income, even though a substantial portion of BB deposits go to the government and state enterprises. 


\section{Risk Mitigation: Financial Safety Nets and Crisis Management Capabilities}

34. Contingent risks affecting financial safety nets and crisis management capabilities remain. Weak or failing institutions are usually allowed to keep operating, implicitly incurring the cost of the restructuring. Standard safety nets, such as lender of last resort (LOLR) facilities, have not been introduced and the relevance of those in place, such as the deposit insurance scheme, are yet to be tested. The foreign exchange regulation and BB intervention policy have limited the development of market-based hedging facilities for exchange rate related risks. Furthermore, BB does not have a strategy for self-insurance against external shocks based on targeting an adequate stock of reserves.

\section{A. Bank Resolution Framework}

35. A sound and efficient banking system must provide for an orderly exit of banks that do not pass the market test. Above all, banks that become insolvent should be taken from their owners and sold to new owners in part (any good parts) or in whole or wound down and liquidated. Allowing insolvent banks to continue "normal" operations usually results in increasing costs of restructuring and additional losses (and ultimately a greater burden on tax payers for bailing out the depositors), which tends to distort the market and thwart the development of the rest of the banking sector.

36. Financial institutions have never been allowed to fail in Bangladesh. The Banking Companies Act (BCA) of 1991 provides BB and/or the government extensive power to suspend banks' licenses, suspend their businesses, and wind up banking companies. While these powers are adequate in some respects for an orderly and least-cost resolution of an insolvent bank, they have never been used. The authorities currently prefer instead to rehabilitate an insolvent bank under enhanced supervision rather than implement a least-cost resolution.

\section{B. Lender of Last Resort and Emergency Liquidity Assistance}

37. There is no formal procedure for emergency liquidity assistance. Banks may borrow up to five-day maturity at the repo facility of the central bank if they have the required collateral and if $\mathrm{BB}$ accepts their requests. However, there is neither a mechanism to provide liquidity for longer periods on a case-by-case basis nor overnight standing facilities. The need for a LOLR is considerably reduced by the practice of rescheduling obligations for distressed institutions.

\section{Deposit Insurance Scheme}

38. The deposit insurance scheme is operational and covers a significant share of the insured deposits. However, the relevance of the premium collected is challenged by the absence of effective liquidation procedures. The Department of Offsite Supervision of BB has been entrusted to administer the activities of the Deposit Insurance System (DIS). However, the specifics of the role of the DIS in failed banks' resolution have not been determined. Therefore, 
the scheme is expected to function as a pay box. ${ }^{18}$ Finally, a payment has never been made out of the fund as no bank has been liquidated as yet.

\section{Financial Stability Policy Framework}

\section{BB's regulatory powers have been strengthened since the 2003 FSAP but much} remains to be done to bring regulation and supervision into accord with best international practices, especially given the growing sophistication of banking. BB has made efforts continued to align its prudential norms more closely with international standards and enforce these more strictly, however there is considerable scope for improvement. The Government has brought amendments to the Bangladesh Bank Order 1972 and BCA of 1991 by the Bank Companies (Amendment) Ordinance 2007. The amendments gave the central bank greater autonomy and authority on exchange rate and monetary policy, as well as bank supervision. However, more needs to be done to upgrade regulation and supervision, starting with greater provision of autonomy for BB in its supervisory actions.

\section{A. Supervisory and Regulatory Framework}

40. Supervision is fragmented and organized by type of intermediary and sector, mainly as a result of lack of coordination. BB is responsible for the supervision of government-owned, domestic private and foreign commercial banks, government-owned specialized banks (agriculture, industry and housing); off-shore banks; nonbank financial institutions; exchange houses and cash remittance services. Thousands of microfinance companies operate in Bangladesh, but only 400 are registered with the MRA. Credit cooperatives operate under the supervision of the Cooperative Societies Ordinance, under the Ministry of Law, Justice and Parliamentary Affairs. Despite the considerable efforts of BB, the regulatory and supervisory system falls short of international standards (Appendix 6), and there is considerable scope for improve the regulations, strengthen enforcement, and enhance supervisory practices. ${ }^{19}$

41. Although financial conglomerates do not exist in the Bangladesh market, there are a number of linkages and activities within the financial arena that cross the supervisory boundaries, making coordination with other domestic supervisors imperative. ${ }^{20}$ For

\footnotetext{
${ }^{18}$ SCBs are not charged a risk-based premium even though they are often problem banks, and they enjoy an implicit subsidy for their total deposits given that the government is unlikely to let an SCB be liquidated and depositors to suffer losses. Also, the netting of the premium base by the lower of the minimum liquidity requirement or actual liquid assets does not encourage additional liquidity self-insurance.

${ }^{19}$ For example, the classification of assets and loss provisioning requirements are not consistent with international accepted practices. Additionally, the supervisory practices in this area are generous and facilitate reporting lower than needed provisions.

${ }^{20}$ The summary assessment of the observance of the Basel Core Principles in Appendix 6 provides further references to consolidated and cross-border banking supervision.
} 
example, a number of commercial banks have received licenses from the SEC to conduct merchant banking.

42. BB is taking initiatives to modernize the supervisory processes. Initial steps to shift from compliance-based supervision to risk based-supervision have been taken. Outreach to other supervisors via attachments and training programs have been the primary source of input to this shift in supervisory approach. Although BB Supervisors are to be lauded for their efforts and commitment to this very large undertaking, these preliminary steps toward risk-based supervision are in need of considerable further effort since supervisors are still applying outdated techniques and not truly conducting risk-based supervision.

43. A number of problems still undermine the regulatory and supervisory process. One basic issue is the Government's legal authority to alter actions taken by BB. Other issues include, in terms of supervision, classification of loans, rescheduling, and provisions, which appear to be very liberal. Notwithstanding considerable efforts, the supervisors' assessment of risk management needs improvement. No single overall exposure limit exists and the definition of related parties needs to be strengthened. Supervision of market, interest rate, and liquidity risk needs to be upgraded. Better communication between on-site and off-site supervision is needed and the supervision of the state-owned banks needs improvement. coordination with supervisors of other financial activities, as does supervision of home-host relationships.

\section{B. Basel Capital Accord Implementation}

\section{BB has attempted to upgrade risk management practices in the banking sector by} issuing guidelines on a number of core risk areas. Their effectiveness is, however, compromised by outdated supervisory processes (Appendix 6). Following recommendations of the previous FSAP, BB has issued guidelines on asset liability management, foreign exchange rate risk, internal control \& corporate governance, anti-money laundering, credit risk, and information and communication technology. The guidelines serve as minimum standards, on the basis of which banks are expected to build their own manuals. In practice, the supervisor relies heavily on checklists to assess whether policies and procedures are in place. A major impediment for this transition is the lack of coordination and information exchange between the various supervisory departments of $\mathrm{BB}$, and between the supervisory directorate and the monetary directorate of BB.

\section{Implementation of Basel II is intended for 2010, however BB is cautioned that} considerable efforts by the industry as well as by the supervisors will be needed to ensure successful realization. $\mathrm{BB}$ has been working on strengthening the supervisory framework (Pillar 2). However, it is viewed by the assessors as work in progress and a number of practices and regulations should more closely match international accepted practices. Additionally, the heavy involvement of the Government in the supervisory mandate will have to be addressed in order to remove its impact on market discipline (Pillar 3). 


\section{AML/CFT Framework}

\section{The Asia/Pacific Group on Money Laundering (APG) conducted an assessment of} Bangladesh's anti-money laundering and combating the financing of terrorism (AML/CFT) framework and the resulting Mutual Evaluation Report was adopted by its plenary meeting in July 2009. ${ }^{21}$ Bangladesh faces significant risks of money laundering (ML) and terrorism financing. The report acknowledged efforts by the authorities to address these issues, including creation of the Financial Intelligence Unit (FIU) within BB. Bangladesh has set up its FIU, which is performing its core functions. Nevertheless, a strengthened legal environment, addressing notably gaps in the scope of both the ML and the TF offenses, shortcomings in AML/CFT preventive measures for the private sector, and the lack of effective sanctions for legal persons, would play a critical role in creating the basis for a strong financial system. $^{22}$ To ensure effectiveness, Bangladesh should prepare as soon as possible a ML/TF riskanalysis and adopt at the highest level a national AML/CFT strategy to widen and implement effective measures to address national risks.

\footnotetext{
${ }^{21}$ The APG is the Financial Action Task Force (FATF) style regional body of which Bangladesh is a member.

22 The authorities stated in their comments that Money Laundering was first criminalized in the 2002 Money Laundering Prevention Act (MLPA) and, following legal challenge, the new government reissued the Money Laundering Prevention Ordinance (MLPO) 2008 and Anti-Terrorism Ordinance (ATO) 2008 as Acts of parliament with retrospective effect from the day of their issuance as ordinances. Bangladesh criminalized terrorism financing in the Anti-Terrorism Ordinance (ATO) in 2008 and has ratified the UN Terrorist Financing Convention.
} 
Table 1. Bangladesh: Key Economic Indicators, FY2007-14 1/

Nominal GDP (FY09): US\$89 billion Population (FY08): 142.5 million GDP per capita (FY08): US $\$ 554$

Poverty rate (FY05): 40.8 percent
Main export (percent of total): garments and textiles (79)

FDI (percent of GDP, FY09): US\$941 million (1.0)

Government debt: 45.4 percent of GDP

Foreign government debt: 53 percent of total debt

\begin{tabular}{|c|c|c|c|c|c|c|c|c|}
\hline & \multirow[b]{2}{*}{ FY07 } & \multirow[b]{2}{*}{ FY08 } & Est. & \multicolumn{5}{|c|}{ Projections } \\
\hline & & & FY09 & FY10 & FY11 & FY12 & FY13 & FY14 \\
\hline \multicolumn{9}{|l|}{ National income and prices (percent change) } \\
\hline Real GDP & 6.4 & 6.2 & 5.9 & 5.0 & 5.8 & 6.0 & 6.0 & 6.0 \\
\hline GDP deflator & 6.8 & 8.0 & 6.4 & 6.4 & 6.0 & 5.0 & 5.0 & 4.5 \\
\hline CPI inflation (annual average) & 7.2 & 9.9 & 6.7 & 7.8 & 7.0 & 6.0 & 5.0 & 4.5 \\
\hline CPI inflation (end of period) & 9.2 & 10.0 & 2.2 & 10.0 & 7.2 & 5.0 & 5.0 & 4.0 \\
\hline \multicolumn{9}{|l|}{ Investment and savings (percent of GDP) } \\
\hline Gross investment & 24.5 & 24.2 & 23.3 & 24.2 & 24.4 & 24.6 & 24.8 & 25.4 \\
\hline Private & 19.0 & 19.3 & 18.6 & 19.0 & 19.2 & 19.4 & 19.5 & 20.2 \\
\hline Public & 5.4 & 5.0 & 4.7 & 5.2 & 5.2 & 5.2 & 5.2 & 5.2 \\
\hline National savings & 25.9 & 25.1 & 26.2 & 27.1 & 25.8 & 25.4 & 25.6 & 26.2 \\
\hline Private & 24.1 & 23.4 & 24.9 & 25.7 & 24.7 & 24.3 & 24.4 & 25.0 \\
\hline Public & 1.7 & 1.7 & 1.3 & 1.4 & 1.1 & 1.2 & 1.2 & 1.2 \\
\hline \multicolumn{9}{|l|}{ Central government operations (percent of GDP) } \\
\hline Total revenue & 10.2 & 10.8 & 10.4 & 10.7 & 10.5 & 10.6 & 10.7 & 10.7 \\
\hline Tax & 8.2 & 8.8 & 8.6 & 8.8 & 8.8 & 8.9 & 9.0 & 9.0 \\
\hline Nontax & 2.0 & 2.0 & 1.8 & 1.9 & 1.7 & 1.7 & 1.7 & 1.7 \\
\hline Total expenditure & 13.4 & 15.9 & 14.1 & 14.8 & 14.8 & 14.9 & 14.9 & 14.9 \\
\hline Current expenditure & 9.1 & 9.6 & 9.8 & 10.0 & 10.1 & 10.2 & 10.2 & 10.2 \\
\hline Of which: Interest payments & 1.9 & 2.5 & 2.4 & 2.3 & 2.4 & 2.5 & 2.5 & 2.5 \\
\hline Of which: Subsidies and transfers & 3.0 & 3.4 & 3.8 & 3.9 & 3.9 & 3.8 & 3.8 & 3.8 \\
\hline Annual Development Program & 4.0 & 3.4 & 3.2 & 3.3 & 3.3 & 3.3 & 3.3 & 3.3 \\
\hline Other expenditures & 0.3 & 3.0 & 1.1 & 1.5 & 1.4 & 1.4 & 1.4 & 1.4 \\
\hline Overall balance (excluding grants) & -3.2 & -5.1 & -3.7 & -4.0 & -4.3 & -4.2 & -4.2 & -4.1 \\
\hline Primary balance & -1.3 & -2.6 & -1.3 & -1.7 & -1.9 & -1.8 & -1.7 & -1.6 \\
\hline Financing (net) & 3.2 & 5.1 & 3.7 & 4.0 & 4.3 & 4.2 & 4.2 & 4.1 \\
\hline Domestic & 1.9 & 2.6 & 2.4 & 2.6 & 3.0 & 3.0 & 2.9 & 2.8 \\
\hline External (including grants) & 1.3 & 2.5 & 1.3 & 1.5 & 1.2 & 1.2 & 1.3 & 1.3 \\
\hline Total central government debt (percent of GDP) & 48.8 & 46.7 & 45.3 & 44.0 & 44.1 & 44.0 & 43.8 & 43.6 \\
\hline \multicolumn{9}{|c|}{ Money and credit (end of fiscal year; percent change) } \\
\hline Net domestic assets & 12.6 & 18.3 & 17.6 & 14.7 & 16.6 & 16.9 & 16.5 & 16.1 \\
\hline Credit to private sector & 15.1 & 25.1 & 14.6 & 15.7 & 16.6 & 16.6 & 17.1 & 17.2 \\
\hline Broad money (M2) & 17.1 & 17.6 & 19.2 & 18.8 & 17.2 & 16.6 & 16.4 & 16.2 \\
\hline \multicolumn{9}{|l|}{ Balance of payments (in billions of U.S. dollars) } \\
\hline Exports, f.o.b. & 12.1 & 14.2 & 15.6 & 16.1 & 17.3 & 19.2 & 21.8 & 24.6 \\
\hline (Annual percent change) & 15.8 & 17.4 & 10.1 & 3.2 & 7.6 & 11.1 & 13.3 & 12.9 \\
\hline Imports, f.o.b. & -15.5 & -19.5 & -20.3 & -21.0 & -23.5 & -26.0 & -29.0 & -32.3 \\
\hline (Annual percent change) & 16.6 & 25.6 & 4.2 & 3.5 & 11.7 & 11.0 & 11.5 & 11.2 \\
\hline Current account & 1.0 & 0.7 & 2.5 & 2.9 & 1.5 & 0.9 & 1.0 & 1.1 \\
\hline (Percent of GDP) & 1.4 & 0.9 & 2.8 & 2.9 & 1.4 & 0.8 & 0.8 & 0.8 \\
\hline Gross official reserves (in billions of U.S. dollars) & 5.1 & 6.1 & 7.5 & 10.9 & 12.3 & 13.2 & 14.5 & 16.2 \\
\hline In months of imports of goods and services & 2.7 & 3.1 & 3.6 & 4.7 & 4.8 & 4.6 & 4.6 & 4.6 \\
\hline Exchange rate (taka per US\$; period average) & 68.8 & 68.6 & 68.8 & $\ldots$ & $\ldots$ & $\ldots$ & $\ldots$ & $\cdots$ \\
\hline Nominal effective rate $(2000=100)$ & 66.9 & 63.6 & 66.8 & $\cdots$ & $\cdots$ & $\cdots$ & $\ldots$ & $\cdots$ \\
\hline Real effective rate $(2000=100)$ & 83.8 & 84.9 & 90.2 & & $\ldots$ & $\ldots$ & $\ldots$ & $\ldots$ \\
\hline Terms of trade (percent change) & -3.0 & 0.7 & 2.5 & & & & & \\
\hline Nominal GDP (in billions of taka) & 4,725 & 5,458 & 6,149 & 6,867 & 7,698 & 8,568 & 9,536 & 10,563 \\
\hline
\end{tabular}

Sources: Data provided by the Bangladesh authorities; and Fund staff estimates and projections.

1/ Fiscal year begins July 1 . 
Table 2. Bangladesh: Financial Soundness Indicators

\begin{tabular}{|c|c|c|c|c|c|}
\hline & 2004 & 2005 & 2006 & 2007 & 2008 \\
\hline \multicolumn{6}{|l|}{ Capital Adequacy } \\
\hline Regulatory capital to risk-weighted assets & 6.9 & 7.3 & 5.1 & 7.4 & 10.1 \\
\hline State-owned commercial banks (BB) & 7.9 & 7.9 & 8.0 & 1.9 & 2.4 \\
\hline State-owned commercial banks (Corrected) & 8.4 & 9.4 & -7.8 & 6.4 & 7.8 \\
\hline Specialized development banks & 8.0 & 8.1 & 8.0 & 8.6 & 8.8 \\
\hline Private commercial banks & 6.9 & 6.6 & 6.7 & 7.8 & 8.6 \\
\hline Foreign commercial banks & 20.3 & 20.6 & 19.7 & 17.8 & 19.2 \\
\hline Regulatory capital to assets & 4.3 & 4.7 & 3.3 & 4.6 & 6.5 \\
\hline Regulatory Tier I capital to risk-weighted assets & 5.7 & 6.0 & 3.3 & 5.3 & 7.4 \\
\hline Regulatory Tier I capital to total assets & 3.5 & 3.8 & 2.1 & 3.3 & 4.8 \\
\hline Non-performing loans to regulatory capital & 265.1 & 195.9 & 275.3 & 205.9 & 116.1 \\
\hline \multicolumn{6}{|l|}{ Asset Quality Standards } \\
\hline Non-performing loans to total loans & 17.5 & 13.2 & 12.8 & 14.5 & 11.2 \\
\hline State-owned commercial banks & 8.6 & 8.9 & 22.8 & 29.0 & 28.0 \\
\hline Specialized development banks & 25.0 & 18.0 & 14.3 & 13.5 & 11.7 \\
\hline Private commercial banks & 7.4 & 5.1 & 4.9 & 5.4 & 5.1 \\
\hline Foreign commercial banks & 4.3 & 3.1 & 2.8 & 2.9 & 3.7 \\
\hline Loan provisions to total non-performing loans & 26.8 & 28.3 & 45.2 & 43.0 & 50.1 \\
\hline Loan provisions to total loans & 4.7 & 3.7 & 5.8 & 6.2 & 5.6 \\
\hline \multicolumn{6}{|l|}{ Profitability } \\
\hline Return on equity & -12.1 & 12.1 & -37.3 & 18.7 & 20.3 \\
\hline State-owned commercial banks & -213.6 & -41.8 & -419.0 & -16.3 & 68.5 \\
\hline Specialized development banks & -17.8 & -29.2 & -15.8 & -10.5 & -9.5 \\
\hline Private commercial banks & 61.1 & 65.0 & 73.7 & 59.0 & 46.4 \\
\hline Foreign commercial banks & 57.3 & 42.0 & 46.2 & 48.6 & 46.1 \\
\hline Return on assets & -0.5 & 0.6 & -1.2 & 0.9 & 1.3 \\
\hline State-owned commercial banks & -3.2 & -0.6 & -6.6 & -0.3 & 1.1 \\
\hline Specialized development banks & -1.0 & -1.6 & -0.9 & -0.6 & -0.6 \\
\hline Private commercial banks & 1.4 & 1.4 & 1.5 & 1.4 & 1.4 \\
\hline Foreign commercial banks & 3.3 & 3.4 & 3.3 & 3.2 & 2.9 \\
\hline \multicolumn{6}{|l|}{ Sensitivity to market risk } \\
\hline Net open position in foreign exchange to capital & 20.3 & 15.2 & 31.5 & 14.7 & 9.9 \\
\hline \multicolumn{6}{|l|}{ Composition of credit (in percent of total) } \\
\hline Oil and Gas & 1.2 & 1.4 & 1.8 & 0.8 & 0.9 \\
\hline Industry (other) & 33.4 & 31.3 & 32.2 & 34.5 & 36.0 \\
\hline Agriculture & 9.8 & 9.0 & 8.2 & 7.7 & 6.8 \\
\hline Forestry & 3.1 & 2.5 & 2.4 & 2.1 & 1.8 \\
\hline Trade & 24.5 & 22.6 & 22.1 & 24.3 & 24.0 \\
\hline Construction & 3.3 & 3.8 & 4.1 & 3.4 & 3.3 \\
\hline Households & 3.4 & 3.4 & 3.3 & 4.7 & 4.8 \\
\hline Other & 21.2 & 26.1 & 26.0 & 22.6 & 22.5 \\
\hline
\end{tabular}

Sources: Bangladesh Bank; and Fund staff estimates. 
Appendix I. Exchange Rate, FX Intervention, and Deposits

Figure 1. Asia: Deposits/GDP in Selected Countries

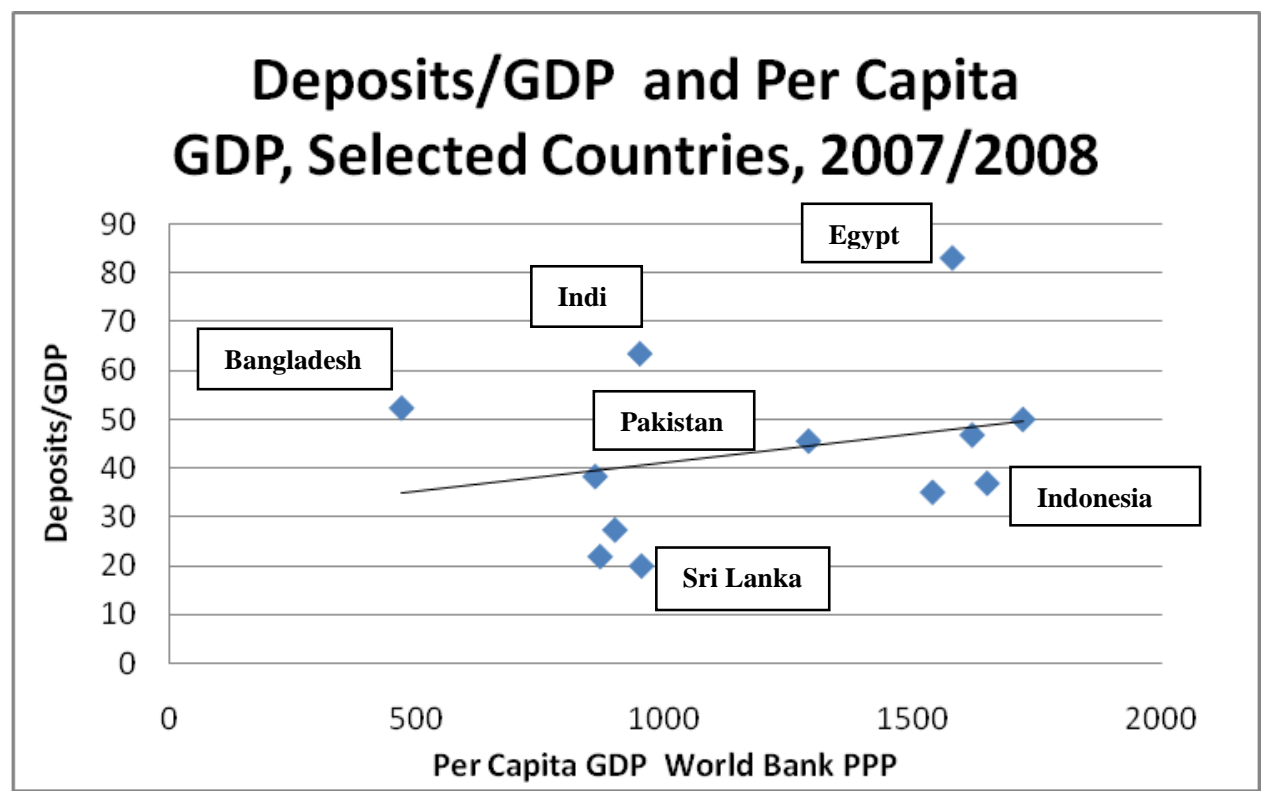

Figure 2. Bangladesh: Exchange Rate and Foreign Exchange Intervention

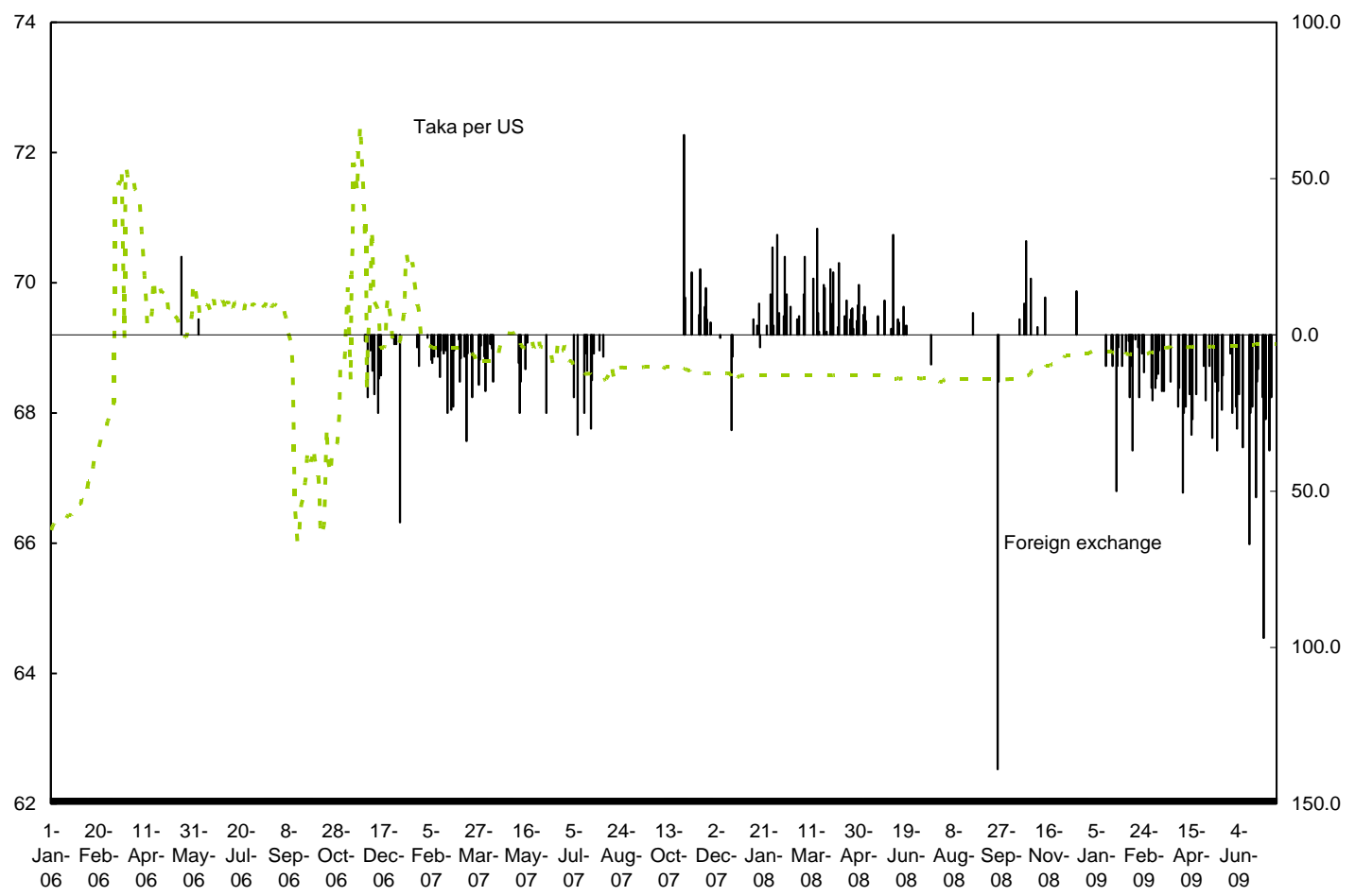




\section{Appendix 2. Monetary Policy Instruments}

Since the implementation of the financial system reform in the early 1990's, BB discontinued the used of direct instruments. However, BB stated in its latest monetary policy document (July 19, 2009) its intension to resort to direct controls on interest rates, commissions, and fees to influence credit distribution.

Repo and reverse repo facilities

The repo allows banks to place bids for funds collateralized by T-bills and T-bonds while the reverse repo is used for the opposite operations. These instruments are not being used as standing facilities, as BB could reject banks' requests at its discretion. Also, they are not used as open market operations because the interest rates are fixed by BB and rarely changed. Since the surge in liquidity and the collapse of short-term interest rates, $\mathrm{BB}$ has refrained from intervening on the domestic currency market.

Figure 4: Money market

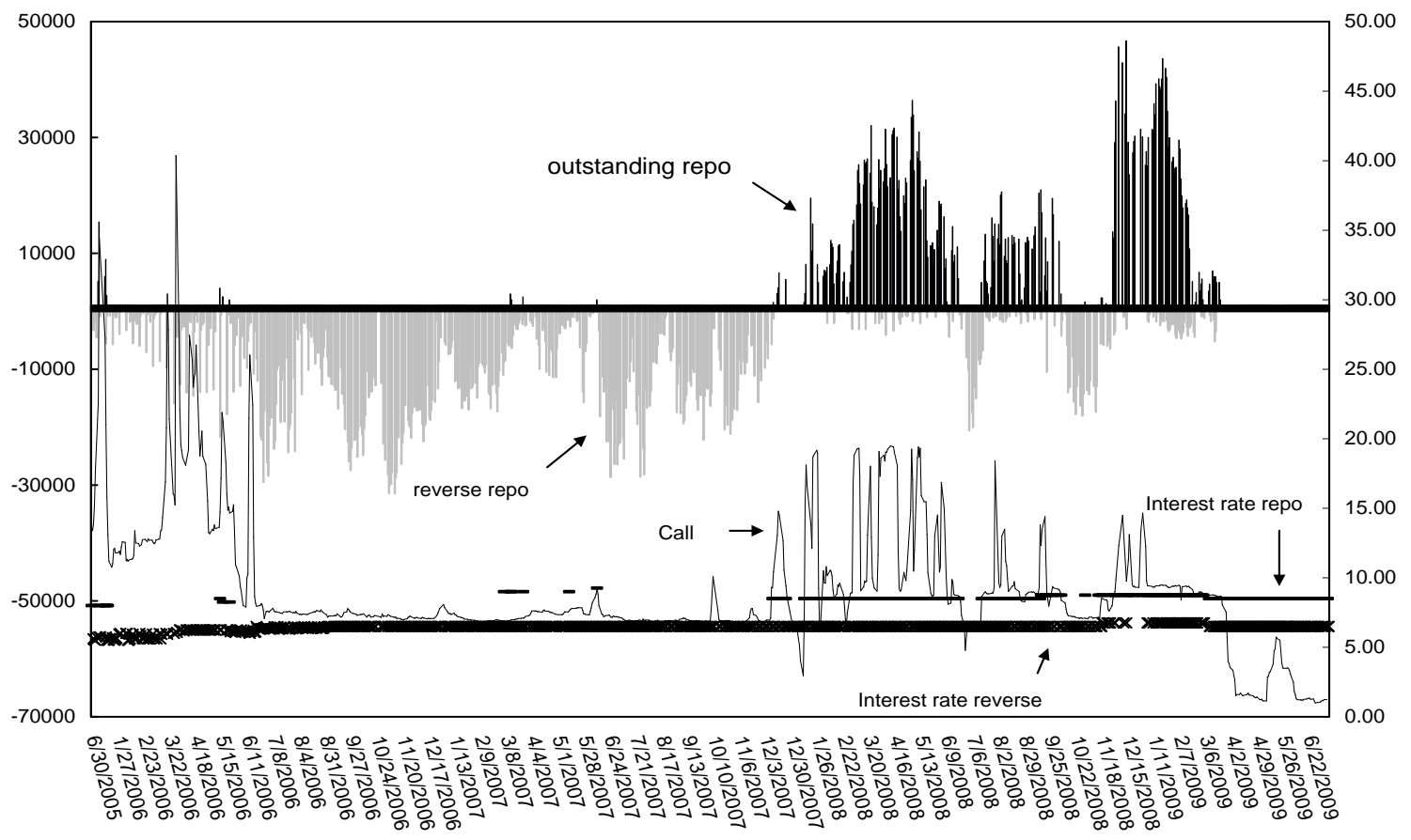

Securities

BB could issue securities at its discretion for 30 and 91 days. BB has not issued any bills during the last 18 months. Treasury bills are dedicated to the Treasury cash flow management.

\section{Lending facilities}

BB manages uncollateralized lending facilities, which rate stands at 5 percent since 2005 . The facility is used to refinance credit by the banks to priority sectors (mostly agriculture) based on promissory note and bills.

Islamic compliant monetary policy instrument

Under the framework of Islamic finance, debt-based instruments cannot earn a positive rate of return and cannot be discounted in a secondary market. This considerably reduces the ability of central bank to use open market operations to manage systemic liquidity and influence interest rates. BB introduced its own sharia compliant bonds in 2006 to help the fast growing Islamic banks to comply with the 10 percent liquidity requirement. The bond issued by BB is a Mudaraba type bond, which could be traded on the secondary market.

\section{Cash reserve requirement}

$\mathrm{BB}$ requests banks to keep five percent of their demand and times liabilities on account at the central bank. Cash in till is not eligible for the CRR.

\section{Statutory liquidity requirement}

In terms of section 33(1) of the Bank Company Act of 1991, the Statutory Liquidity Requirement (SLR) is the minimum (in percentage of total time and demand liabilities) that a scheduled bank has to maintain in liquid assets with BB. The rate was set at 18 percent since 2005 . Specialized banks are exempted while banks guided by Islamic laws are required to keep reserve at the concessional rate of 10 percent. 


\section{Appendix 3. Financial System Structure 2002-2008}

\begin{tabular}{|c|c|c|c|c|c|c|c|c|}
\hline & \multicolumn{4}{|c|}{2002} & \multicolumn{4}{|c|}{2008} \\
\hline & Number & $\begin{array}{l}\text { Billion } \\
\text { taka }\end{array}$ & $\begin{array}{c}\text { Percent } \\
\text { of } \\
\text { Banking } \\
\text { System } \\
\text { Assets }\end{array}$ & $\begin{array}{c}\text { Percent } \\
\text { of } \\
\text { GDP }^{1}\end{array}$ & Number & $\begin{array}{c}\text { Billion } \\
\text { taka }\end{array}$ & $\begin{array}{c}\text { Percent } \\
\text { of } \\
\text { Banking } \\
\text { System } \\
\text { Assets }\end{array}$ & $\begin{array}{l}\text { Percent of } \\
\text { GDP }^{1}\end{array}$ \\
\hline All banks & 51 & $1,276.5$ & 100.0 & 46.8 & 48 & $3,378.2$ & 100.0 & 62.0 \\
\hline State-owned & 9 & 742.2 & 58.1 & 27.2 & 9 & $1,253.2$ & 37.1 & 23.0 \\
\hline SCBs & 4 & 591.5 & 46.3 & 21.7 & 4 & $1,030.9$ & 30.5 & 18.9 \\
\hline SDBs & 5 & 150.7 & 11.8 & 5.5 & 5 & 222.3 & 6.6 & 4.1 \\
\hline Commercial & 42 & 534.3 & 41.9 & 19.6 & 39 & $2,124.9$ & 62.9 & 39.0 \\
\hline Domestic (PCBs) & 30 & 446.4 & 35.0 & 16.4 & 30 & $1,852.9$ & 54.8 & 34.0 \\
\hline Foreign (FCBs) & 12 & 87.9 & 6.9 & 3.2 & 9 & 272.0 & 8.1 & 5.0 \\
\hline Finance companies & 26 & 18.8 & & 0.7 & $29^{5}$ & 90.2 & & 1.7 \\
\hline Microfinance Inst.2/ 3/ & 624 & 37.9 & & 1.4 & 4,200 & 162.0 & & 3.0 \\
\hline Securities markets 4/ & 230 & 65.5 & & 2.4 & 294 & 789.4 & & 14.4 \\
\hline
\end{tabular}

Sources: Bangladesh Bank, Ministry of Commerce, SEC, Development Credit Forum, and MRA.

1/ Based on 2001/02 GDP of Tk. 2,727 billion, 2008 estimated GDP of Tk. 5458 billion.

2/ Microfinance NGOs plus Grameen Bank.

3/ Total loans outstanding used as total assets.

4/ Dhaka Stock Exchange market capitalization in assets column. Listed firms shown under number of firms, excludes mutual funds.

5/Nonbank financial intermediaries. 


\section{Appendix 4. Implementation of the 2003 FSAP Recommendations}

\begin{tabular}{|c|c|}
\hline Recommendation FSAP 2003 & Current Status \\
\hline \multicolumn{2}{|l|}{ State-Owned Commercial Banks } \\
\hline $\begin{array}{l}\text { The poor performance of the SCBs, including } \\
\text { their insolvency, needs to be addressed as soon as } \\
\text { possible. A first step is to strengthen the governance } \\
\text { arrangements for these banks. New, professional } \\
\text { management should be directed to restructure the } \\
\text { banks, curtail lending activities, and reduce } \\
\text { operating costs. They should have complete } \\
\text { discretion over hiring and firing and should be } \\
\text { protected from political interference. They should } \\
\text { undertake a due diligence audit of the loan portfolio } \\
\text { and then formulate detailed resolution plans. }\end{array}$ & $\begin{array}{l}\text { Partially achieved } \\
\text { MOF still appoints boards, no change. } \\
\text { Under the Government reform program, supported } \\
\text { by the World Bank professional management was } \\
\text { chosen competitively, paid international } \\
\text { competitive salaries and directed to follow a } \\
\text { monitored program of resolving NPLs and } \\
\text { improving performance. The MOF retains } \\
\text { discretion over hiring and firing but voluntary } \\
\text { retirement programs have been proposed }\end{array}$ \\
\hline $\begin{array}{l}\text { Comprehensive resolution plans prepared by } \\
\text { their new managements should be adopted for } \\
\text { each bank. They should lead to the privatization (in } \\
\text { whole or in part) or liquidation of each SCBS over a } \\
\text { realistic time period. An interim measure would be } \\
\text { to consolidate the SCBs into one savings bank with a } \\
\text { rationalized branch network. SCBs should be subject } \\
\text { to BB supervision and move to compliance with BB } \\
\text { supervisory regulations. The annual reports of SCBs } \\
\text { and SDBs should be according to international } \\
\text { accounting standards and disclosed in a transparent } \\
\text { fashion to the public. }\end{array}$ & $\begin{array}{l}\text { Partially Achieved. } \\
\text { No long term program along these lines has been } \\
\text { prepared. } \\
\text { SCBs were corporatized as limited liability } \\
\text { companies and BB now has legal authority to } \\
\text { supervise them. BB has monitored the progress of } \\
\text { the restructuring program. } \\
\text { Audited financial statements are now available with } \\
\text { only a short lag from the close of the fiscal year and } \\
\text { accessible on-line. }\end{array}$ \\
\hline \multicolumn{2}{|l|}{ Specialized development banks } \\
\hline $\begin{array}{l}\text { Increase the transparency of subsidies channeled } \\
\text { through SDBs, with a view to replacing them with } \\
\text { direct transfer programs in the medium-term. The } \\
\text { operations of BSB should be discontinued, and the } \\
\text { option of transforming BSRS into a loan collection } \\
\text { agency for other SDBs and SCBs should be studied. } \\
\text { Government should fully compensate BKB and } \\
\text { RAKUB for costs associated with debt forgiveness } \\
\text { and directed credit programs. }\end{array}$ & $\begin{array}{l}\text { Not achieved. } \\
\text { Subsidies are not transparent and often simply } \\
\text { made at the expense of these banks. } \\
\text { No change in the operations of BSB } \\
\text { The government is considering merging BSRS and } \\
\text { BSB }\end{array}$ \\
\hline \multicolumn{2}{|l|}{ Banking supervision } \\
\hline $\begin{array}{l}\text { BB banking supervision needs to implement a model } \\
\text { anti-corruption program for its staff both protecting } \\
\text { staff from corruptive incentives and making known } \\
\text { the high integrity of its personnel. BB needs to: } \\
\text { - } \quad \text { re-evaluate its compensation structure in } \\
\text { order that banking supervision can hire and } \\
\text { retain high quality staff; } \\
\text { - develop better and more integrated } \\
\text { information systems for data reporting and } \\
\text { analysis; } \\
\text { develop systems for analyzing bank } \\
\text { liquidity and market risk and require }\end{array}$ & $\begin{array}{l}\text { Bangladesh Bank continues to be challenged in the } \\
\text { hiring and retaining staff. Efforts are made to hire } \\
\text { college graduates with economics, accounting or } \\
\text { business degrees, however, retention is difficult } \\
\text { given that the pay scale is not within the control of } \\
\text { BB. During the mission, the Governor relayed his } \\
\text { efforts to change this. Also it was acknowledged } \\
\text { that training and a career path is essential to build a } \\
\text { quality supervisory corps. } \\
\text { Since the previous FSAP, the capital requirement } \\
\text { for the banks has been raised and currently is } 10 \\
\text { percent of risk-weighted assets. Despite some } \\
\text { mismatches between the local and international }\end{array}$ \\
\hline
\end{tabular}




\begin{tabular}{|c|c|}
\hline Recommendation FSAP 2003 & Current Status \\
\hline $\begin{array}{l}\text { bankers to under-take such risk } \\
\text { management; } \\
\text { develop data information systems on } \\
\text { default rates by borrowing economic } \\
\text { sectors; } \\
\text { enhanced training program in its training } \\
\text { academy that covers more broadly and } \\
\text { deeply topics in banking supervision; } \\
\text { hire staff with experience in accounting, } \\
\text { commercial banking, and information } \\
\text { technology; } \\
\text { formalize an inter-departmental group or } \\
\text { committee that routinely reviews on- and } \\
\text { off-site examination reports of each } \\
\text { scheduled bank; } \\
\text { more aggressively use its enforcement } \\
\text { powers and develop a transparent system } \\
\text { for documenting interventions; } \\
\text { review minimum capital requirements and } \\
\text { limits on connected lending and large } \\
\text { exposures; and take remedial measures with } \\
\text { institutions that have been assigned to the } \\
\text { Problem Bank Department and do not show } \\
\text { any significant improvement. }\end{array}$ & $\begin{array}{l}\text { standard weightings, the minimum requirement } \\
\text { exceeds the international standard. } \\
\text { Progress in upgrading information gathering and } \\
\text { analysis is mixed; the supervisors appear to be } \\
\text { aware of the banks' liquidity position. However } \\
\text { what seems to be lacking is an assessment of the } \\
\text { quality of banks' risk management activities. The } \\
\text { Credit Information Bureau is in the midst of } \\
\text { implementing an IT system upgrade, which should } \\
\text { facilitate ad-hoc reports. } \\
\text { There is scope for improved coordination between } \\
\text { the various departments involved in supervision, } \\
\text { especially in updating the CAMELS ratings } \\
\text { assigned by off and on site supervision. } \\
\text { Enforcement powers are not aggressively used, } \\
\text { there have been infrequent removals of board } \\
\text { members; however they were based on loan default } \\
\text { rather than failure to maintain fit and proper } \\
\text { standards. Nor has there been aggressive action } \\
\text { taken on the problem banks, evidenced by the fact } \\
\text { that one bank has been in that status for over } 14 \\
\text { years. }\end{array}$ \\
\hline \multicolumn{2}{|l|}{ Bank exit policies } \\
\hline $\begin{array}{l}\text { BB should develop a clear and comprehensive policy } \\
\text { and strategy for resolving problem banks. The } \\
\text { Banking Companies Act should be totally } \\
\text { overhauled. }\end{array}$ & $\begin{array}{l}\text { No policy exists for resolving problem banks. The } \\
\text { Bank Companies Act (BCA) has provision for the } \\
\text { Government of Bangladesh (GOB) to acquire the } \\
\text { undertaking of any bank, if it fails to comply with } \\
\text { BB directives (for corrective action) or if the } \\
\text { operations are detrimental to the interest of the } \\
\text { depositors. Alternatively, the BCA allows the GOB } \\
\text { to declare any bank exempt from any part of the } \\
\text { BCA. These and other articles of the BCA should } \\
\text { be removed or substantially revised. }\end{array}$ \\
\hline \multicolumn{2}{|l|}{ Monetary Policy and Debt Management } \\
\hline $\begin{array}{l}\text { A new central bank law should be adopted giving } \\
\text { BB more autonomy and accountability for } \\
\text { monetary policy, banking supervision, and payment } \\
\text { system oversight. Amendments in this direction were } \\
\text { approved by the Cabinet in February } 2003 \text {. }\end{array}$ & $\begin{array}{l}\text { Partially achieved } \\
\text { A focus prepared a revised regulation that grants } \\
\text { more autonomy to BB. However, the revision as } \\
\text { proposed has not been adopted yet. }\end{array}$ \\
\hline $\begin{array}{l}\text { Responsibilities for debt management and } \\
\text { monetary management need to be disentangled. } \\
\text { MOF should be responsible for the former and BB } \\
\text { should be responsible for monetary policy. }\end{array}$ & $\begin{array}{l}\text { Not achieved } \\
\text { Although staff claim that debt management and } \\
\text { monetary policy decision are taken separately, both } \\
\text { matters are still decided in a join MOF-BB } \\
\text { committee. }\end{array}$ \\
\hline
\end{tabular}




\begin{tabular}{|c|c|}
\hline Recommendation FSAP 2003 & Current Status \\
\hline $\begin{array}{l}\text { BB needs to improve its internal capacity to } \\
\text { formulate and implement monetary and exchange } \\
\text { rate policy, including its capacity to monitor and } \\
\text { forecast market liquidity. }\end{array}$ & $\begin{array}{l}\text { Partially achieved } \\
\text { BB services communicate to its Board an extensive } \\
\text { set of indicator, including excess liquidity by banks } \\
\text { and market indicators, daily. However, the liquidity } \\
\text { forecasting exercise could be improved and its time } \\
\text { horizon should be enlarged. }\end{array}$ \\
\hline $\begin{array}{l}\text { BB needs to broaden and enhance its tools of } \\
\text { liquidity management. These include interbank } \\
\text { repos and reverse repos, a transparent, standing } \\
\text { lending facility (and maybe a deposit facility) a CRR } \\
\text { that allows reserve averaging and remuneration. The } \\
\text { SLR should be phased out over time and redesigned } \\
\text { as a prudential measure. Direct credit to the } \\
\text { government should be strictly limited. }\end{array}$ & $\begin{array}{l}\text { Not achieved } \\
\text { The focus group for the revision of BB act } \\
\text { suggested introducing a LOLR facility. No } \\
\text { significant improvements have been noted for the } \\
\text { other items. }\end{array}$ \\
\hline \multicolumn{2}{|l|}{ Debt management } \\
\hline $\begin{array}{l}\text { The relationship between the MOF and BB in the } \\
\text { area of debt management should be redefined so that } \\
\text { MOF is responsible for managing its cash balances } \\
\text { with BB, issuing t-bills in amounts needed to keep } \\
\text { temporary advances by BB below maximum } \\
\text { permitted levels. All other credit to government } \\
\text { should take the form of BB purchases of securities in } \\
\text { the market (or as noncompetitive bids in the primary } \\
\text { auctions until a secondary market develops). }\end{array}$ & Achieved. \\
\hline $\begin{array}{l}\text { The authorities should eliminate the market's } \\
\text { perception that treasury bills cannot be traded (see } \\
\text { Treasury Rules S.R. 314). Rates on treasury bills } \\
\text { should be at market levels by eliminating the SLR } \\
\text { and BB's automatic lending to government (beyond } \\
\text { limited ways and means advances). }\end{array}$ & Partially Achieved \\
\hline $\begin{array}{l}\text { A Public Debt Office should be established in the } \\
\text { Ministry of Finance. }\end{array}$ & Not Achieved \\
\hline \multicolumn{2}{|l|}{ Payments System } \\
\hline $\begin{array}{l}\text { BB should establish a payment system development } \\
\text { and oversight unit. In addition, it should establish an } \\
\text { advisory body with representatives from the banks } \\
\text { and other payment system stake holders to discuss } \\
\text { payment systems improvements. }\end{array}$ & Established. Oversight function not yet formalized. \\
\hline $\begin{array}{l}\text { Priority should be given to automatic check clearing, } \\
\text { and electronic linkage between BB and its branches } \\
\text { and banks. Both the retail and large value check } \\
\text { clearing systems need technical enhancement. }\end{array}$ & $\begin{array}{l}\text { Achieved. Implementation of an electronic } \\
\text { clearing system is in progress. }\end{array}$ \\
\hline \multicolumn{2}{|l|}{ Financial Sector Development } \\
\hline $\begin{array}{l}\text { The budgetary autonomy, legal powers and capacity } \\
\text { of the SEC need to be improved. SEC funding } \\
\text { should be increased and commission members with } \\
\text { experience in capital markets should be appointed. } \\
\text { The Companies Act of } 1994 \text { should be implemented } \\
\text { by the Registrar of Joint Stock Companies (ROC). }\end{array}$ & $\begin{array}{l}\text { SEC budget and size of staff remains under the } \\
\text { control of MOF. It has adequate powers to } \\
\text { perform its functions although it would benefit } \\
\text { from being given additional powers relating to } \\
\text { enforcement of securities regulation including } \\
\text { access to banking information in its }\end{array}$ \\
\hline
\end{tabular}




\begin{tabular}{|c|c|}
\hline Recommendation FSAP 2003 & Current Status \\
\hline & $\begin{array}{l}\text { investigations and further authority on } \\
\text { cooperation and sharing of information with } \\
\text { domestic and foreign regulators. Size has } \\
\text { remained constant since its founding. The } \\
\text { newly appointed board has some capital } \\
\text { market experience. Salaries have remained } \\
\text { determined by Government scales. } \\
\text { The Registrar should undergo more substantial } \\
\text { reform than its current computerization } \\
\text { program. It should be capable of fulfilling its } \\
\text { role under the CA as well as carrying out its } \\
\text { other functions in a timely and efficient } \\
\text { manner. This may require extensive change, } \\
\text { including the Registrar's place in the current } \\
\text { administration. On enforcement, the Registrar } \\
\text { is still not an effective means of redress. } \\
\text { While supplemented by SEC regulations and } \\
\text { enforcement, the CA provides the foundation } \\
\text { for corporate governance, and its enforcement } \\
\text { depends on the Registrar and the courts. }\end{array}$ \\
\hline $\begin{array}{l}\text { The role of government in developing the sector } \\
\text { should be limited to providing a conducive } \\
\text { environment. Government microfinance programs } \\
\text { should be phased out. The ongoing work on the } \\
\text { regulatory framework for microfinance needs to be } \\
\text { completed on schedule. This framework should } \\
\text { ensure a level playing field for all microfinance } \\
\text { institutions (not just NGOs) in Bangladesh. }\end{array}$ & $\begin{array}{l}\text { Partially achieved. There is an urgent need for } \\
\text { strengthening of the regulatory system for MFI's }\end{array}$ \\
\hline $\begin{array}{l}\text { Developing a long term debt market would benefit } \\
\text { all sectors. Transfer authority over the Department } \\
\text { of Insurance from the Ministry of Commerce to the } \\
\text { Ministry of Finance. } \\
\text { The Money Loan Court Act } 1990 \text { should be } \\
\text { amended to provide for speedy procedures of } \\
\text { decrees and executions. The procedures and rules of } \\
\text { auction need to be reviewed to make auctions } \\
\text { attractive. Legally permitting out of court } \\
\text { foreclosure and sale by private treaty would } \\
\text { significantly improve enforcement. }\end{array}$ & Partially achieved \\
\hline \multicolumn{2}{|l|}{ Anti-Money Laundering } \\
\hline $\begin{array}{l}\text { There is an urgent need to amend the Prevention on } \\
\text { Money Laundering Act } 2002 \text { to implement the } \\
\text { recommendations of the FSAP assessment. }\end{array}$ & $\begin{array}{l}\text { Amendments made. Updated assessment adopted } \\
\text { by APG at July } 2009 \text { Annual Meeting }\end{array}$ \\
\hline
\end{tabular}




\section{Appendix 5. Banking Sector Stress Test Table}

\begin{tabular}{|c|c|c|c|c|c|}
\hline & System & NCBs & PCBs & FBI & DFI \\
\hline \multicolumn{6}{|l|}{ Shocks } \\
\hline Initial CAR & 10.1 & 7.8 & 11.2 & 23.8 & -3.3 \\
\hline \multicolumn{6}{|l|}{ CAR after shock: } \\
\hline NPLs increase & 7.7 & 2.2 & 10.2 & 23.9 & -11.5 \\
\hline Category shift from watch to substandard & 6.6 & 3.8 & 8.0 & 20.9 & -1.1 \\
\hline Appreciation of Taka & 10.1 & 7.9 & 11.3 & 24.1 & -3.3 \\
\hline Depreciation of Taka & 9.9 & 7.5 & 11.1 & 23.6 & -3.3 \\
\hline Upward parallel shift of yield curve in bp & 9.7 & 7.2 & 11.1 & 22.9 & -3.8 \\
\hline Downward parallel shift of yield curve in bp & 10.4 & 8.4 & 11.4 & 24.8 & -2.9 \\
\hline Scenario Analysis & 8.4 & 0.7 & 10.7 & 22.2 & -2.5 \\
\hline \multicolumn{6}{|l|}{ Initial Liquidity Ratios: } \\
\hline SLR Ratio & 23.7 & 30.0 & 19.9 & 35.0 & 11.4 \\
\hline Liquid Assets/Liquid Liabilities (LA/LL) Ratio & 94.8 & 82.4 & 100.3 & 114.5 & 76.9 \\
\hline \multicolumn{6}{|l|}{ Liquidity ratios after Shock: } \\
\hline Run on deposits on LA/LL Ratio & 89.2 & 77.5 & 94.4 & 107.8 & 72.4 \\
\hline Run on deposits on SLR ratio & 19.8 & 23.7 & 17.2 & 30.8 & 9.7 \\
\hline
\end{tabular}




\section{Appendix 6. Observance of Financial Sector Standards and Codes: Basel Core Principles for Effective Banking Supervision}

This Appendix contains a summary assessment of the observance of the Basel Core Principles for Effective Banking Supervision (BCP). This assessment was conducted as part of the FSAP updated evaluation of the Bangladesh financial system from July 13 to July 30, 2009. As agreed, the supervisory framework was assessed against the BCP methodology issued in October 2006. Besides the essential criteria, the additional criteria were included in the analysis. The assessment was conducted by Mr. Miquel Dijkman, World Bank and Diane Mendoza, a consultant with the IMF.

The assessment was based on a range of sources, including:

- self-assessment of compliance with the 25 Basel Core Principles completed by BB management team, the legal and regulatory framework for banking supervision, off site monitoring reports, a bank annual report, guidelines issued by BB addressing six core risk areas and various other reporting schedules submitted by the banks as well as numerous documents available on the Bangladesh Bank's website.

- During their stay, the assessors held extensive discussions with the supervisory staff of BB, which includes: Department of Off Site Supervision, Department of Banking Inspection I; Department of Banking Inspection II, Banking Regulation and Policy Department, Anti-Money Laundering Department; Credit Information Bureau, Department of Financial Institutions and the Deposit Insurance Representatives, a division of the Department of Off Site Supervision.

- The assessors also met with representatives of Ministry of Finance, banking institutions and the Institute of Chartered Accountants of Bangladesh.

\section{- Information and methodology used for assessment}

The assessment of compliance with each principle is made on a qualitative basis. A four-part assessment system is used: compliant; largely compliant; materially non-compliant; and noncompliant.

The ratings assigned during this assessment are not comparable to the ones assigned in the unpublished 2003 FSAP, as the bar to measure the effectiveness of a supervisory framework has been raised in the new methodology. New criteria have also been added while existing ones have been redefined.

\section{Institutional and macroeconomic setting and market structure—overview}

The Bangladesh financial sector is dominated by the banking industry. The early emphasis on state-led banking reflected the Government's active pursuit of industrial policies to engender 
growth. State-owned banks were regarded as the appropriate vehicles by which savings could be channeled to the sectors of the economy with the best growth prospects. State-owned banks generally suffered from poor governance and political interference, with loans distributed to politically connected enterprises and state owned enterprises, without proper oversight. Despite recent progress, this legacy is still reflected in high NPL ratios and weak solvency.

Private banks started to enter the market in the 1980s. Bangladesh's private banks have rapidly gained market share at the expense of the state-owned commercial banks (SOCB) and currently hold more than 50 percent of total deposits, versus 30 percent for the SCBs. A number of foreign banks have also entered the market, although with some 8 percent of deposits their market share is limited due to the lack of a widespread network of branches. Specialist development banks account for the remaining share of deposits. Islamic banking is offered either through divisions of commercial banks or as full-service Islamic banks. Offshore banks are also present in Bangladesh, they are branches of local and foreign banks and their operations are limited to deposit taking and financing activities in the Bangladesh Export Processing Zones.

The Government of Bangladesh has indicated its desire to divest of the state owned banks, and took an initiative in late 2008 to make them limited liability companies. The Ministry of Finance, in consultation with the SEC and BB allowed the banks to move their accumulated losses into capital surpluses based on the notion of Goodwill. The accumulated losses were converted in a Goodwill asset that will be amortized out of future profits. This accounting treatment is questionable and concerns remain regarding the true financial condition of these banks.

Bangladesh Bank is responsible for the licensing, supervision and regulation of the banking sector and fulfills this through on-site inspections and off-site supervision, which includes licensing, data collection and monitoring, placement of corrective actions and imposition of sanctions. Since the last 2003 FSAP, BB has undertaken a significant effort to upgrade risk management practices in the banking sector by issuing guidelines on a number of core risk areas. Guidelines have been issued for Asset Liability Management (ALM), foreign exchange rate risk, internal control \& corporate governance, Anti-Money Laundering $(\mathrm{AML})$, credit risk and information and communication technology.

The effectiveness of the guidelines is however compromised by outdated supervisory processes. CAMELS ratings are assigned to the banks, and rely primarily on historic reviews of banks' operations: no forward-looking assessments regarding the risk profiles of the banks are performed by BB Supervisors. Although the concept of risk-based supervision has been introduced, the supervisory process is still compliance-based. In practice, the supervisor relies heavily on checklists to assess whether policies and procedures are in place. Limited effort is undertaken to verify the quality of the risk management efforts and to assess their adequacy given the overall characteristics of the respective bank. Another factor impeding the transition to a risk-based approach is the lack of coordination and information exchange 
between the various supervisory departments of $\mathrm{BB}$, and between the supervisory directorate and the monetary directorate of BB. Human resource policies, including frequent mandatory job rotation and uncompetitive pay scales are another important factor.

Other financial sector participants supervised by Bangladesh Bank (BB) include non-bank financial institutions (NBFI), money remitters and money changers. NBFI are governed by the Financial Institutions Act, 1993, can accept deposits, except checking accounts, are subject to the cash reserve requirement as well as the statutory liquidity requirement. The MRA oversees the operation of 3,650 NGO-MFI, of which 402 were fully licensed as of Dec 2008 and 2,749 small entities were operating under a special extension. The largest MFI, Grameen Bank operates under the Grameen Bank Ordinance 1983. Although they are not licensed by BB, many MFIs collect deposits from members under the coverage of the MRA Act. They are not subject to cash reserve or statutory reserve requirements and are not covered by the deposit insurance scheme. The total value of MFI deposits, including Grameen is US 756 million, held in almost 32 million depositor accounts. Cooperative credit societies, governed by the Cooperative Societies Ordinance, under the Ministry of Law, Justice and Parliamentary Affairs also operate in Bangladesh, and represent a nominal portion of the financial services. The SEC regulates capital market intermediaries, including stock exchanges, stock brokers and merchant banks. Most merchant banks are owned by commercial banks and operate as a division within the bank. The Controller General of Insurance regulates insurance companies.

\section{Pre conditions for Effective Bank Supervision}

- Public infrastructure is not well developed. Lack of a central land registry to evidence property ownership and to record liens has resulted in fraudulent and duplicate land titles. This raised the potential for multiple and unknown liens on property and marginalized the collateral protection for loans.. Asset valuations are performed but standards for determining and reporting valuations do not exist. Approximately 200 chartered accountant firms operate in Bangladesh, including representatives of the five large international firms. Companies listed on the stock exchange are required to provide their annual audited annual financial statements to the Securities \& Exchange Commission. Banks report monthly or quarterly, depending on loan size and whether it is in default and are required to obtain information regarding the borrower's history during the loan underwriting process

- Lack of effective market discipline. BB has effectively imposed a moratorium for the entry of new banks. It has also demonstrated reluctance to let weak banks fail, with prolonged rehabilitation periods for problem banks. Level playing field issues are also present, with Bangladesh Bank authorizing increased loan disbursement limits for the four state owned banks. While the lack of entry and exit weakens market discipline, politically inspired social objectives and direct regulation directly interfere with banks' business decisions. A deposit insurance scheme was established in 1984 and revised in 2004; and all scheduled banks are required to be members of the fund. 


\section{Main Findings}

Since the FSAP in 2003 BB supervisors have taken a number initiatives to strengthen and upgrade supervision. Efforts include amendments to the relevant banking legislation, the development and issuance of guidelines on core risk areas and development of supervisory tools to begin risk-based supervision. While the efforts have been considerable, and BB is lauded for their efforts, they are not sufficient to justify higher ratings. In the shift to the risk based supervision, the supervisors will need to conduct qualitative assessments of the banks' risk management activities. Procedures used by the supervisors are still compliance-based and appear to focus on verifying the existence of policies and risk management procedures rather than determining if they appropriate to the size and nature of the bank's activities. The following summarizes the main findings of the detailed assessment of compliance with the BCP.

- Objectives, independence, powers, transparency and cooperation (CP1). BB is responsible for the supervision of banks and financial institutions, as enshrined in the Bangladesh Bank Act. BB does not have the functional independence, due primarily to articles in the Banking Company Act, 1991, that allow the Government of Bangladesh to participate in the supervisory mandate. The impact of this participation ranges from approval of salary and benefits of BB staff to the exempting any bank from any provisions of the Banking Company Act. Government's participation in the supervisory mandate does not appear to be isolated and it undermines the supervisors' authority, distorts the market and offers disincentives for the industry. Further, the transparency of the supervisory actions is clouded by decisions that may not have been based on prudential considerations. The professionalism and integrity of supervisory staff are recognized. There is a need to strengthen the corps of supervisors and through coordination with BB Human Resources Department, reduce the impact of employeerotation policies. Further, there is a need to build capacity to conduct effective supervision of bank risk and risk management. Legal protection for the supervisors is provided, as referenced in the law, and should be strengthened with an explicit statement to expand disciplinary powers. The legal framework of BB has not been upgraded since 2003, although six guidelines have been issued to address the banks' core risk areas, which do not have the force of law. Subsequent to the last FSAP, the Bangladesh Bank Order was amended, with a clause that specified that BB was responsible for the supervision and regulation of the banks and financial institutions. Banking Company Act, 1991 was also amended and strengthened many requirements of that law.

- Licensing and structure (CPs 2-5). Steady growth in MFI has raised the issue of whether those MFIs are taking deposits from the public. Coordination with the Microfinance Regulatory Authority to address this issue is essential. There is concern about the very broad nature of the activities in which the banks may engage. A de facto moratorium on new bank licenses has been in effect for about five years. A guideline has been developed to address applications for bank licenses, and is still in draft. 
- Prudential regulation and requirements (CPs 6-18). A minimum capital adequacy ratio (CAR) of 10 percent is required, and for the most part complies with the definition in the Basel I capital accord. The authority of BB to require increases in the amount of capital is vague and explicit language granting such authority should be included in the amendments to the BCA. Further, BB does not have the power to require banks to adopt a forward-looking approach and to set capital levels in anticipation of changes in market conditions or adverse events. Currently, failure of a bank to maintain the minimum capital level results in a monetary penalty. An important issue is that loss recognition is comparatively slow, as loans are only recognized as loss after 60 months of past due status. Another concern is that banks have the option to declassify loans classified by the examiners, upon Board approval. Additionally, the accounting treatment of interest on NPLs and recovered loans is not consistent with international accounting standards. A recurring theme with regard to the various risk categories is that $\mathrm{BB}$ faces a considerable challenge to upgrade its largely compliance-based framework to a risk-based framework. Bangladesh has made serious strides to improve compliance with international Anti Money Laundering (AML) standards. A Financial Integrity Unit (FIU) has been set up within $\mathrm{BB}$, which is responsible for receiving and analyzing suspicious transaction reports.

- Methods of ongoing banking supervision (CPs 19-21). The on-site supervision department performs comprehensive and special inspections. It also assesses the strength of banks on the basis of CAMELS methodology. The off-site supervision department also performs CAMELS analyses and is charged with the follow-up of corrective measures. Banks with unsatisfactory CAMELS score are submitted to the Early Warning Scheme and are transferred to the problem bank department. The SCBs are however exempted from this. BB faces the challenge to supplement CAMELS with a more risk-based and forward-looking approach, that would involve considerable qualitative judgment.

- Accounting and disclosure (CP 22). BB requires Bangladeshi banks to submit audited financial reports and audited profit and loss accounts, with steep punishments for deliberate misreporting. BB has detailed prescriptions on the format of the financial statements. Mark to market is the most prevalent valuation method, while IAS is the main accounting method, although IFRS is also permitted. The recent recapitalization of the SCBs illustrates however that consistency and prudence in accounting methods are in practice an issue of serious concern.

- Corrective and remedial powers of supervisors (CP 23). BB relies primarily on the issuance of directions to bring about corrective action. It can do so if it is in the public interest to do so, while the respective bank is required to report progress to $\mathrm{BB}$. BB can remove directors if this is in the interest of depositors. Non-compliance with laws can be fined. The fine structure is currently under Parliamentary review. BB's heavy reliance on directions in part reflects a limited range of alternative corrective mechanisms. A general reluctance to resort to winding up procedures further adds to the problem, as banks in the problem bank department are allowed prolonged rehabilitation periods. 
- Consolidated and cross-border banking supervision (CPs 24-25). Bangladesh has few banking groups, which largely is a result of the 5 percent voting cap and a maximum of 10 percent stock ownership. In practice this does not fully inhibit the formation of financial groups and expansion into new business activities as the range of permitted activities is quite broad. A recently proposed change in supervisory policy would require the scheduled banks that own merchant banks licenses to operate them as subsidiaries. Also a local bank recently purchased a majority interest in an investment bank and its affiliate brokerage house. These two facts will require an expansion of consolidated supervision activities. Prudential standards are in practice imposed on a consolidated basis, but the BCA does not explicitly require banks to do so. Bangladeshi banks have modest foreign operations, mostly in the form of branches. BB verifies the financial soundness of the applying institution and checks a feasibility report. Foreign banks in Bangladesh are exclusively branches and are broadly subject to similar prudential requirement, although the licensing process for opening new branches is less stringent for FCBs than for Bangladeshi banks. The main challenge for Bangladesh is to further develop its contacts with overseas prudential supervisors. The intention to seek new MoU arrangements is to be encouraged, but is no substitute for developing close professional relations on an informal basis.

\section{Recommended Action Plan and Authorities' response.}

The authorities stated that significant steps are been taken to enhance the supervisory and regulatory framework which, in their view, will result in improved observance of the BCPs. These steps include:

- to revise $\mathrm{BBO}$ and $\mathrm{BCA}$ and take actions to improve the supervision, within the confines of the existing laws - in particular, address pressing issues such as the ability to make adhoc information requests, expanding the definition of related parties, approval of transfer of significant ownership and authorizing a sanctions regulation

- to upgrade the risk-based supervisory practices; streamline work flow and information channels; and exploit the data maintained by the CIB to provide industry-wide and bank specific credit risk data.

- to identify upgrades to the legal framework - in particular, strengthening BB's authority, minimizing government participation in the supervisory mandate, updating the regulations, directions and policies issued by $\mathrm{BB}$ and giving the guidelines a legal basis are the main considerations.

The following table contains the specific recommendations to bring the Bangladesh supervisory framework up to international standards. 


\section{Recommended Action Plan to Improve Compliance with the Basel Core Principles}

\begin{tabular}{|c|c|}
\hline Reference Principle & Recommended Action \\
\hline Independence (BCP 1.2) & $\begin{array}{l}\text { Change BBO and BCA to remove the Government's } \\
\text { involvement in the supervisory mandate. }\end{array}$ \\
\hline Legal frame (BCP 1.3) & $\begin{array}{l}\text { Upgrade BBO, BCA, regulations, policies, directions; } \\
\text { and give guidelines the weight of law. }\end{array}$ \\
\hline Legal powers (BCP 1.4) & $\begin{array}{l}\text { Amend } \mathrm{BBO} \text { and } \mathrm{BCA} \text { to provide power to issue } \\
\text { regulations, to take corrective actions, }\end{array}$ \\
\hline Permissible Activities (BCP 2) & $\begin{array}{l}\text { Coordinate with other supervisory agencies to } \\
\text { eliminate gaps in coverage (i.e. merchant bank } \\
\text { licenses, microfinance institutions' deposits); consider } \\
\text { narrowing the scope of permissible activities or } \\
\text { increasing capital requirement for more complex } \\
\text { operations }\end{array}$ \\
\hline Licensing criteria (BCP 3) & $\begin{array}{l}\text { Set and publish criteria for new bank applicants, level } \\
\text { the playing field for branch licensing. }\end{array}$ \\
\hline Transfer of significant ownership (BCP 4) & $\begin{array}{l}\text { Subject any transfer of } 5 \text { percent stock ownership to } \\
\text { review and preapproval of BB; conduct fit and proper } \\
\text { tests on the proposed owner }\end{array}$ \\
\hline Major Acquisitions (BCP 5) & $\begin{array}{l}\text { Review major acquisitions to determine if risk profile } \\
\text { of institution is impacted; amend law to narrow the } \\
\text { scope of allowed acquisitions and to require pre- } \\
\text { approval of major acquisitions. }\end{array}$ \\
\hline Capital Adequacy (BCP 6) & $\begin{array}{l}\text { Establish supervisory process that would consider the } \\
\text { risk profile of the bank when determining its capital } \\
\text { ratio. }\end{array}$ \\
\hline Risk Management Process (BCP 7) & $\begin{array}{l}\text { Develop comprehensive supervisory processes and } \\
\text { programs to determine if banks have adequate risk } \\
\text { strategies and management practices in place. }\end{array}$ \\
\hline Credit Risk (BCP 8) & $\begin{array}{l}\text { Establish processes to assess the suitability of credit } \\
\text { risk management activities }\end{array}$ \\
\hline Problem assets, provisions and reserves (BCP 9) & $\begin{array}{l}\text { Revise and tighten requirements for classification, } \\
\text { rescheduling, writing off of loans and provisioning for } \\
\text { loan losses. Remove ability of bank to de-classify } \\
\text { loans. }\end{array}$ \\
\hline Large Exposure Limits (BCP 10) & $\begin{array}{l}\text { Establish an aggregate limit for all exposures. } \\
\text { Currently, individual limits exist for loans, equity } \\
\text { investments, and other exposures. }\end{array}$ \\
\hline CP 11 Exposures to related parties & $\begin{array}{l}\text { Broaden definition of related parties to include major } \\
\text { shareholders, senior management, key staff, and their } \\
\text { direct business interests. }\end{array}$ \\
\hline CP 12 Country and transfer risks & $\begin{array}{l}\text { Formulate policies for identifying, measuring, } \\
\text { monitoring and controlling country risk. This includes } \\
\text { setting limits or demanding specific provisions. }\end{array}$ \\
\hline CP 13 Market risk & $\begin{array}{l}\text { Upgrade supervisory practices by monitoring the } \\
\text { specificities of market risk limits and their } \\
\text { appropriateness given the characteristics of the } \\
\text { institution involved. }\end{array}$ \\
\hline
\end{tabular}




\begin{tabular}{|c|c|}
\hline Reference Principle & Recommended Action \\
\hline CP 14 Liquidity risk & $\begin{array}{l}\text { Upgrade supervisory practice by assessing the } \\
\text { adequacy of liquidity management strategies given the } \\
\text { specific characteristics. }\end{array}$ \\
\hline CP 15 Operational risk & $\begin{array}{l}\text { Issuance of a separate guideline on operational risk, } \\
\text { based on definition Basel Committee of operational } \\
\text { risk. }\end{array}$ \\
\hline CP 16 Interest rate risk in the banking book & $\begin{array}{l}\text { Upgrade supervisory practice by assessing the } \\
\text { adequacy of interest rate profile, given the specific } \\
\text { features of the institution involved. }\end{array}$ \\
\hline CP 17 Internal control and audit & $\begin{array}{l}\text { Strengthen supervision on internal audit function by } \\
\text { focusing on preconditions, i.e. independence and } \\
\text { availability of resources. }\end{array}$ \\
\hline CP 18 Abuse of financial services & $\begin{array}{l}\text { Raise reporting levels by stepping up enforcement on } \\
\text { AML legislation. Close loopholes by extending AML } \\
\text { requirements to unlicensed deposit-taking institutions. } \\
\text { Raise fines. }\end{array}$ \\
\hline CP 19 Supervisory approach & $\begin{array}{l}\text { Enhance coordination and information exchange } \\
\text { between on-site and off-site supervision. Abolish } \\
\text { differential treatment SCBs with regard to EWS and } \\
\text { transfer to problem bank department. }\end{array}$ \\
\hline CP 20 Supervisory techniques & $\begin{array}{l}\text { Supplement CAMELS with qualitative judgment in } \\
\text { order to make supervision more risk-based and } \\
\text { forward-looking. }\end{array}$ \\
\hline CP 21 Supervisory reporting & $\begin{array}{l}\text { Establish legal powers to make ad hoc information } \\
\text { requests and to sanction for not delivering information } \\
\text { on a timely basis. }\end{array}$ \\
\hline CP 22 Accounting and disclosure & $\begin{array}{l}\text { Enhance monitoring of accounting methods. Fight } \\
\text { imprudent practices }\end{array}$ \\
\hline CP 23 Corrective and remedial powers of supervisors & $\begin{array}{l}\text { Develop additional tools besides directions, including } \\
\text { appointment restructuring administrator and cease and } \\
\text { desist order. Allow for winding up of non-viable } \\
\text { institutions }\end{array}$ \\
\hline CP 24 Consolidated supervision & $\begin{array}{l}\text { Expand reporting and supervisory requirements to } \\
\text { include consolidated supervision. }\end{array}$ \\
\hline CP 25 Home-host relationships & $\begin{array}{l}\text { Intensify contacts with overseas supervisors, both } \\
\text { formally (extension of existing MoUs) and informally. }\end{array}$ \\
\hline
\end{tabular}

${ }^{23}$ The Basel Committee has defined operational risk as the risk of loss resulting from inadequate or failed internal processes, people and systems or from external events. The definition includes legal risk but excludes strategic and reputational risk. 


\section{Appendix 7. Bangladesh: Financial Stability Diagnostic and Assessment Matrix for FSSAs}

\section{Overall level of concern}

\begin{tabular}{lc}
\hline $\begin{array}{l}\text { Nature/Source of Main } \\
\text { Threats }\end{array}$ & Likelihood of severe \\
& realization of threat in the \\
next [1-3] years
\end{tabular}

\section{Medium}

Currently, there is excess liquidity in the banking system with strong growth potential, improved fiscal stance, and strong commitment of the authorities to macro and financial stability.

\section{Slowdown in remittances.}

\section{Expected impact on financial stability if threat is realized}

High

Dependence of the financial system and domestic credit on remittances is high. Mitigating factors are the generally higher quality of the international banks when compared against stateowned banks.

Although remittances have held up - with growth of 22 percent in the just-ended fiscal year-a fall in the number of workers leaving the country pose a risk for the future. Downside risk of a more protracted or a deepening global slowdown, which could impact negatively the continued employment prospects of Bangladeshi expatriates.

Sustained reductions in remittances could trigger a sharp downturn in the macro-financial environment (with negative consequences for the exchange rate and capital position of banks) and a deterioration in the repayment capacity of borrowers that receive those remittances as a source of income.

Second round effects would involve a severe impact on the economy through reductions in consumption and investment activities.

The impact on the financial system and the economy will be linked to the duration of the slowdown. In particular, if the slowdown is temporary and the authorities chose to soften the impact on the exchange rate through FX-market sales, the secondround effects on dollar-denominated loan quality deterioration associated with an exchange rate depreciation will be muted (stress tests performed provide a broad quantitative sense of the impact of this shock).

\section{Medium-to-High}

\section{Medium}

Credit risk continues to have a larger impact than any other single factor risk.

\section{A rapid deterioration in credit risks conditions, especially affecting state-owned banks.}

State-owned banks are currently below the CAR minimum. All nine foreign banks operating in Bangladesh, all were resilient.

Competitive pressures exist between banks and the large
When shocks are performed assuming a uniform 20 percent deterioration of the loan portfolio for top down and bottom up analysis, the banking sector capital asset ratio requires significant recapitalization efforts to meet the regulatory minimum of 10 percent.

It is likely that the risk profile of those loans outside the regulatory perimeter remains higher relative to those on the books of the supervised institutions. In the event of a negative credit shock, some microfinance institutions would be severely affected. 
microfinance institutions, which are less regulated and tax free.

Non-prudential government intervention, such as interest rate ceilings, moral suasion, directed credit and explicit requirements to ease debt service for some sectors of the economy, increases risks, reduces transparency, and creates inefficiencies.

Moreover, inadequate information, attributable to nontransparent accounting and reporting, affects market discipline.
Loan classification, provisioning, and even capital remain uneven in the banking sector, may aggravate potential vulnerabilities and magnify the impact of the shock.

\section{State-owned banks low capital position}

Low

Despite recent gains, SCBs'

finances remain weak and ad hoc government demands put an additional stress on profitability.

SCBs' performance may also be hindered by BB's special prudential limitation on their loan growth to 15 percent of paid in capital. However, removal of this limitation needs to be complemented by measures to ensure the SCB's do not engage in excessive lending.

\section{High}

Government pressured banks to open low return L/Cs for petroleum, fertilizer and food during the oil/food price run up.

The government's moral suasion and targets for various types of lending decrease profitability_potentially more so than for PCBs.

SCBs like all banks, may suffer lower returns due to the recent ceilings on lending rates.

\section{Medium}

Some risks for the stability of the financial system are actually arising from the strong position of Bangladesh's balance of payments and the monetary and exchange rate frameworks.

Unsterilized intervention aimed at keeping the taka stable has led to excess liquidity and has pushed down short-term interest rates.

\section{High}

High excess liquidity arising from unsterilized interventions could lead to rapid credit growth and subsequent inflationary pressures.

Persistent excess liquidity may eventually turn into a credit boom, inflation - such as of housing prices - and a financial crisis once that bubble bursts. In particular, if excess liquidity eventually fuels inflation and a concomitant real exchange rate appreciation, the competitiveness of the export sector would be affected and, given the exposure of banks to this sector, there could be a deterioration in loan credit quality. 
institutions have increased their

dependency on short-term

funding, exposing themselves to

the fluctuation of the money

market.

5. Sharp commodity
price (mostly oil)
increase would
negatively deteriorate
the macro-financial
environment.

Low

Supply is not constrained

Demand has not yet increased abruptly.

\section{Medium}

Looking forward, rising commodity prices could erode the recent strong improvement in the balance of payments

Could trigger a substantial increase in credit risk of households and corporates.

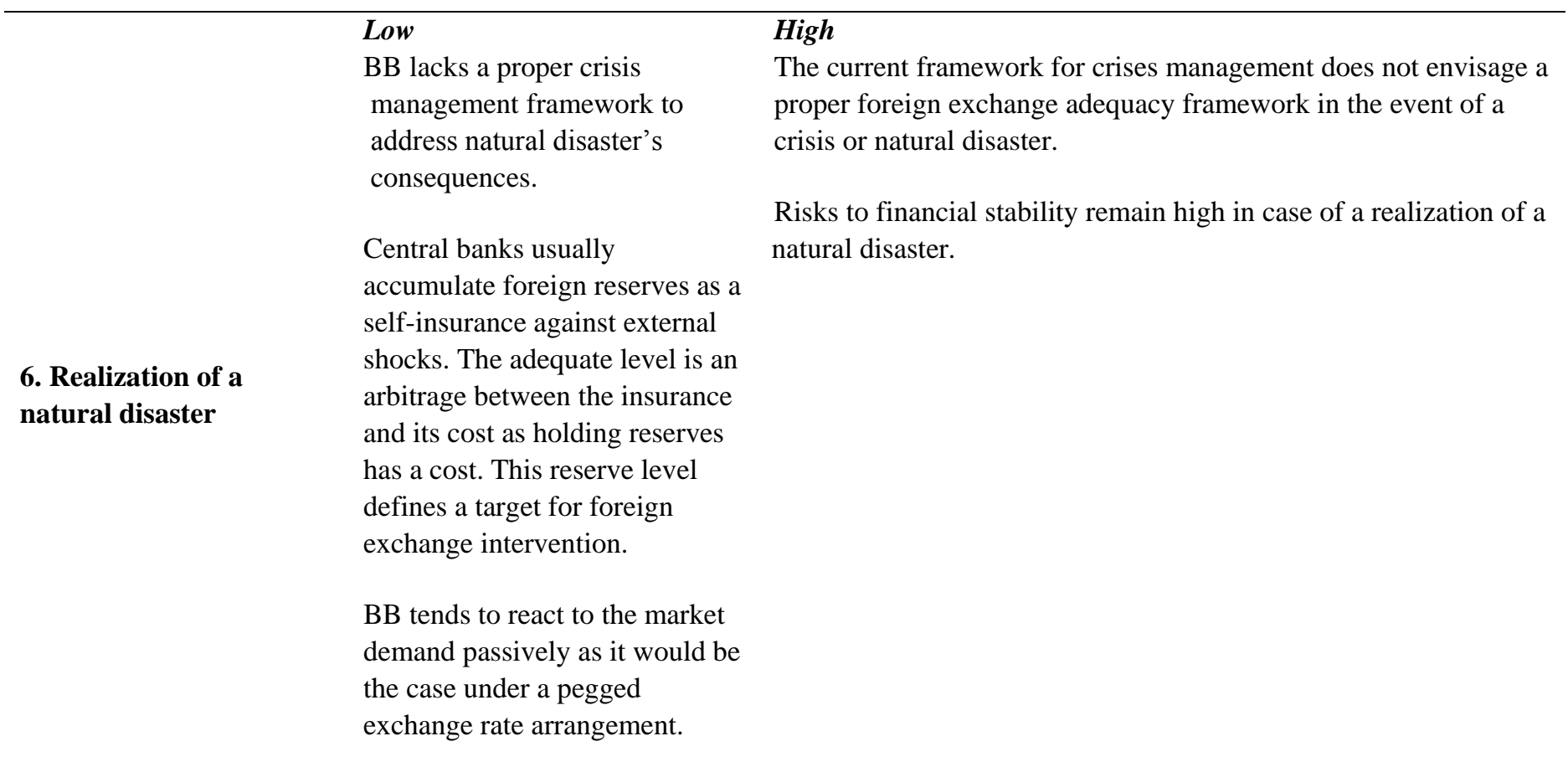

